\title{
Possibilities and Limitations of Non-Invasive Analytical Methods in the Examination of Garnet- and Niello-Inlaid Precious Metal Objects - Case Study of Three Polychrome Animal-Style Silver Buckles from the $5^{\text {th }}$-Century Carpathian Basin
}

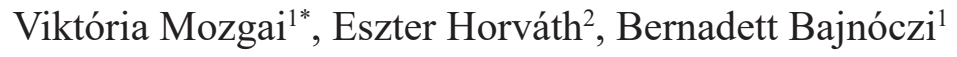 \\ ${ }^{I}$ Institute for Geological and Geochemical Research, Research Centre for Astronomy and Earth Sciences, Eötvös Loránd Research Network (ELKH), \\ Budaörsi út 45, 1112 Budapest, Hungary \\ ${ }^{2}$ Department of Archaeometry and Archaeological Methodology, Institute of Archaeological Sciences, Eötvös Loránd University, Múzeum körút 4/B, \\ 1088 Budapest, Hungary
}

\section{ARTICLE INFO}

\section{Article history:}

Received: $9^{\text {th }}$ September 2020

Accepted: $12^{\text {th }}$ April 2021

DOI: http://dx.doi.org/10.24916/iansa.2021.1.4

\section{Key words:}

polychrome precious metal object

Carpathian Basin

garnet provenance

gilding

hXRF

SEM-EDX

$\mu-\mathrm{XRD}$

\begin{abstract}
$A B S T R A C T$
The use of non-destructive and non-invasive analytical methods is widespread in the archaeometric study of metal objects, particularly in the case of precious metal artefacts, from which sampling is not, or in a limited way, allowed due to their high value. In this study, we highlight the main advantages and limitations of non-destructive analytical methods used on three polychrome animal-style silver buckles from the mid-to-late- $5^{\text {th }}$-century Carpathian Basin. Optical microscopic observations, handheld XRF, SEM-EDX and $\mu$-XRD analyses were performed to determine the chemical composition of the metals and their decoration (gilding, garnet and niello inlays), as well as the microtexture and mineralogical composition of the niello, in order to gain a better understanding of the materials used and reconstruct the manufacturing techniques in detail. The buckles were manufactured from relatively high-quality silver derived from the re-use of gilded silver scrap metal and intentionally alloyed with brass or leaded brass. The presence of mercury indicated the use of fire gilding. The niello inlays are composed of mixed silver-copper sulphides, even reaching the composition of pure copper sulphide; this is the first time, when copper sulphide niello is observed on a silver object. The almandine garnets most probably originate from Southern India and Sri Lanka.
\end{abstract}

\section{Introduction}

The use of non-destructive and non-invasive analytical methods is widespread in the archaeometric study of metal objects, particularly in the case of precious metal artefacts, from which sampling is not allowed (or only in a very limited way) due to their high value. However, beside the advantage of their non-destructive nature, each analytical method has its own limitations as well, which have to be taken into consideration during data evaluation and interpretation (e.g., precision, accuracy, surface morphology, surface alterations, and object size). The advantages and limitations of non-

*Corresponding author. E-mail: mozgai.viktoria@csfk.org destructive analytical methods are presented in this paper in connection with the detailed archaeometric study of three cast, silver, rhomboid belt buckles from the second half of the $5^{\text {th }}$ century AD (Figure 1$)$.

This study aims to determine the elemental composition of the metal alloy and characterise the decoration techniques (gilding, niello and garnet inlays). The different character of these four components set different opportunities and limitations to the investigation. The analysis of metal alloy has significance primarily in the reconstruction of the organisational background of the production; i.e., in revealing the sort of preceding use and application phases, which attests the economic value of the given raw materials in the period, and on the other 
A
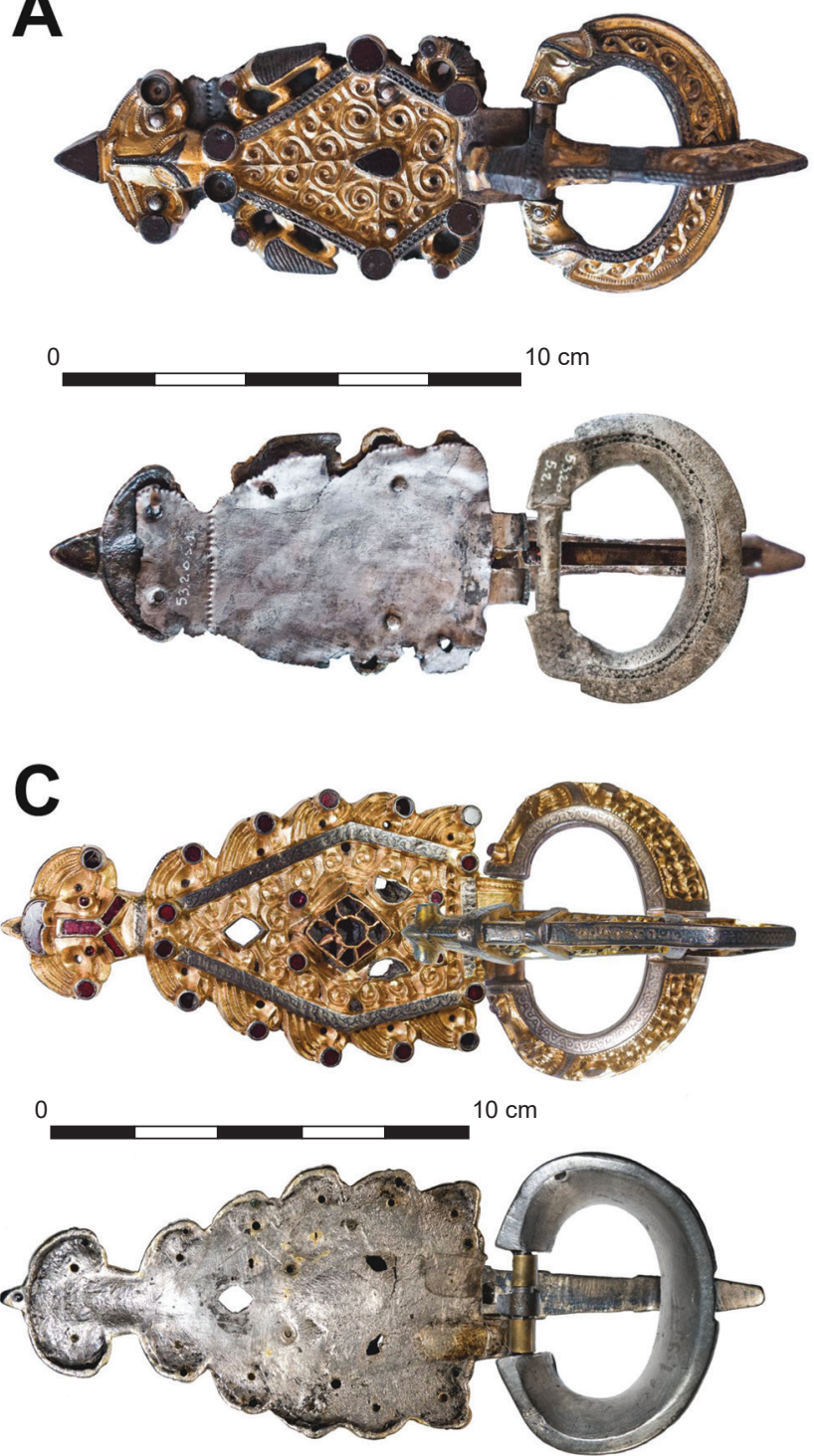

B
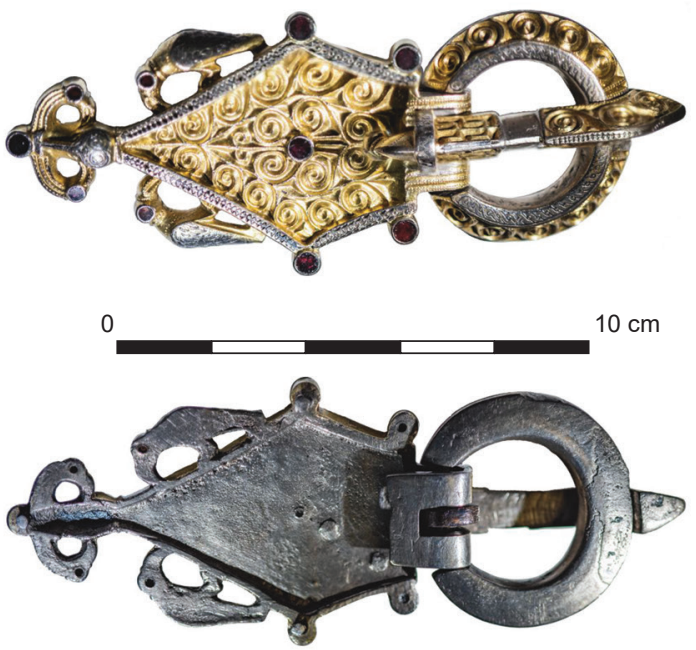

D

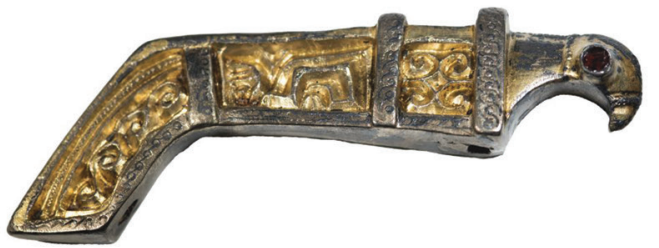

0

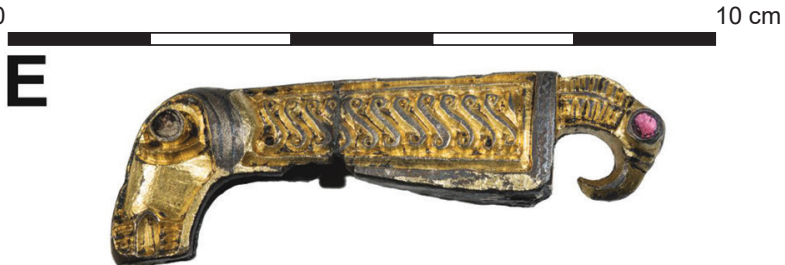

Figure 1. The analysed polychrome animal-style rhomboid silver buckles. A: the buckle from Zsibót-Domolospuszta (buckle ZsD) (Janus Pannonius Museum, Pécs); B: the buckle from Bácsordas (Karavukovo) (buckle B/K) (Hungarian National Museum, Budapest); C: the buckle with an unknown provenance (buckle UP) (Hungarian National Museum, Budapest). The tongues associated with the buckle with unknown provenance (buckle UP). D: tongue decorated with a bird's head; E: tongue decorated with a bird and boar head (photos: E. Horváth).

hand, in assessing the presence of any alloying practice and standardisation.

From the middle of the $5^{\text {th }}$ century AD, silver became a more important raw material than gold. The combination of these two precious metals provided a new opportunity to enhance the polychrome effect. The use of uncoated gold material or gold plates on silver objects, typical for the Hunnic Period, was superseded by the use of (fire)gilding (Horváth et al., 2019; Mozgai et al., 2019b).

In the case of niello, a black silver and/or copper sulphide inlaying material, its artificial, recipe-like character is the key to identify the process of its making and fusing. Dissimilarities in the composition and technology may reflect different goldsmithing traditions or even workshop practices. Since the discussed buckles have close relations with late
Roman military equipment in several aspects (Böhme, 1974), determination of the mineralogical composition and microtexture of niello inlays may provide relevant new results. Analytical data are expected to prove or disprove the continuity of the late Roman niello recipes and technology.

In contrast with the silver alloy and niello inlay, the garnet inlays represent a primary raw material of natural origin. During data evaluation, no chemical transformation/alteration or human intervention needs to be considered. Therefore, in the case of garnet, we could target the localisation of potential geological sources or the identification of their character (e.g., alluvial or mined garnet). The proportions of major, minor and trace elements, as well as the combination of special inclusions, have proved to be the fingerprint evidence for (certain/particular) garnet 
provenances. Corresponding archaeometric investigations are being performed worldwide, used as a reference for our new measurements (e.g., Greiff, 1998; Calligaro et al., 2002; Gilg et al., 2010; Schmetzer et al., 2017; Calligaro and Périn, 2019; Pion et al., 2020; Then-Obłuska et al., 2021). These studies are performed in order to extend our knowledge about the used trade links and the organisational background of supply in the Early Middle Ages, when garnet inlaid jewellery had an unprecedented spread.

\section{Archaeological background and analysed artefacts}

The belt buckles involved in the analysis represent one of the most emblematic metal artefacts in the middle-second half of the $5^{\text {th }}$ century $\mathrm{AD}$. Their main characteristics are the silver metal, the rhomboid shape and the decoration in polychrome animal style (Table 1; Figure 1). All of the three examples discussed here are from the Middle Danube Region (Figures 1-2). The first one is from Zsibót-Domolospuszta

Table 1. The analysed polychrome animal-style rhomboid silver buckles, their decoration techniques and the number of garnet inlays. L: length; H: height; W: width.

\begin{tabular}{|c|c|c|c|c|c|c|c|c|c|}
\hline \multirow[t]{2}{*}{ Provenance site } & \multirow[t]{2}{*}{$\begin{array}{l}\text { Abbreviated } \\
\text { name }\end{array}$} & \multirow[t]{2}{*}{ Sizes } & \multicolumn{4}{|c|}{ Decoration techniques } & \multicolumn{3}{|c|}{$\begin{array}{c}\text { Garnet inlays } \\
\text { (original/missing) }\end{array}$} \\
\hline & & & Chip-carving & Gilding & Niello inlays & Garnet inlays & Loop & Tongue & Plate \\
\hline Zsibót-Domolospuszta & buckle ZsD & $\begin{array}{l}\mathrm{L}: 15.3 \mathrm{~cm} \\
\mathrm{~W}: 6.3 \mathrm{~cm} \\
\mathrm{H}: 0.5 \mathrm{~cm}\end{array}$ & $\mathrm{X}$ & $\mathrm{X}$ & $\mathrm{X}$ & $\mathrm{X}$ & - & $2 / 0$ & $14 / 2$ \\
\hline $\begin{array}{l}\text { unknown } \\
\text { (Hungary) }\end{array}$ & buckle UP & $\begin{array}{l}\mathrm{L}: 22.1 \mathrm{~cm} \\
\mathrm{~W}: 7.4 \mathrm{~cm} \\
\mathrm{H}: 3.7 \mathrm{~cm}\end{array}$ & $\mathrm{X}$ & $\mathrm{X}$ & $\mathrm{X}$ & $\mathrm{X}$ & $4 / 1$ & $2 / 1-4 / 3$ & $40 / 15$ \\
\hline $\begin{array}{c}\text { Bácsordas } \\
\text { (Karavukovo) }\end{array}$ & buckle $\mathrm{B} / \mathrm{K}$ & $\begin{array}{l}\mathrm{L}: 14.7 \mathrm{~cm} \\
\mathrm{~W}: 5.9 \mathrm{~cm} \\
\mathrm{H}: 2.7 \mathrm{~cm}\end{array}$ & $\mathrm{X}$ & $X$ & $\mathrm{X}$ & $\mathrm{X}$ & - & $2 / 1$ & $10 / 0$ \\
\hline
\end{tabular}

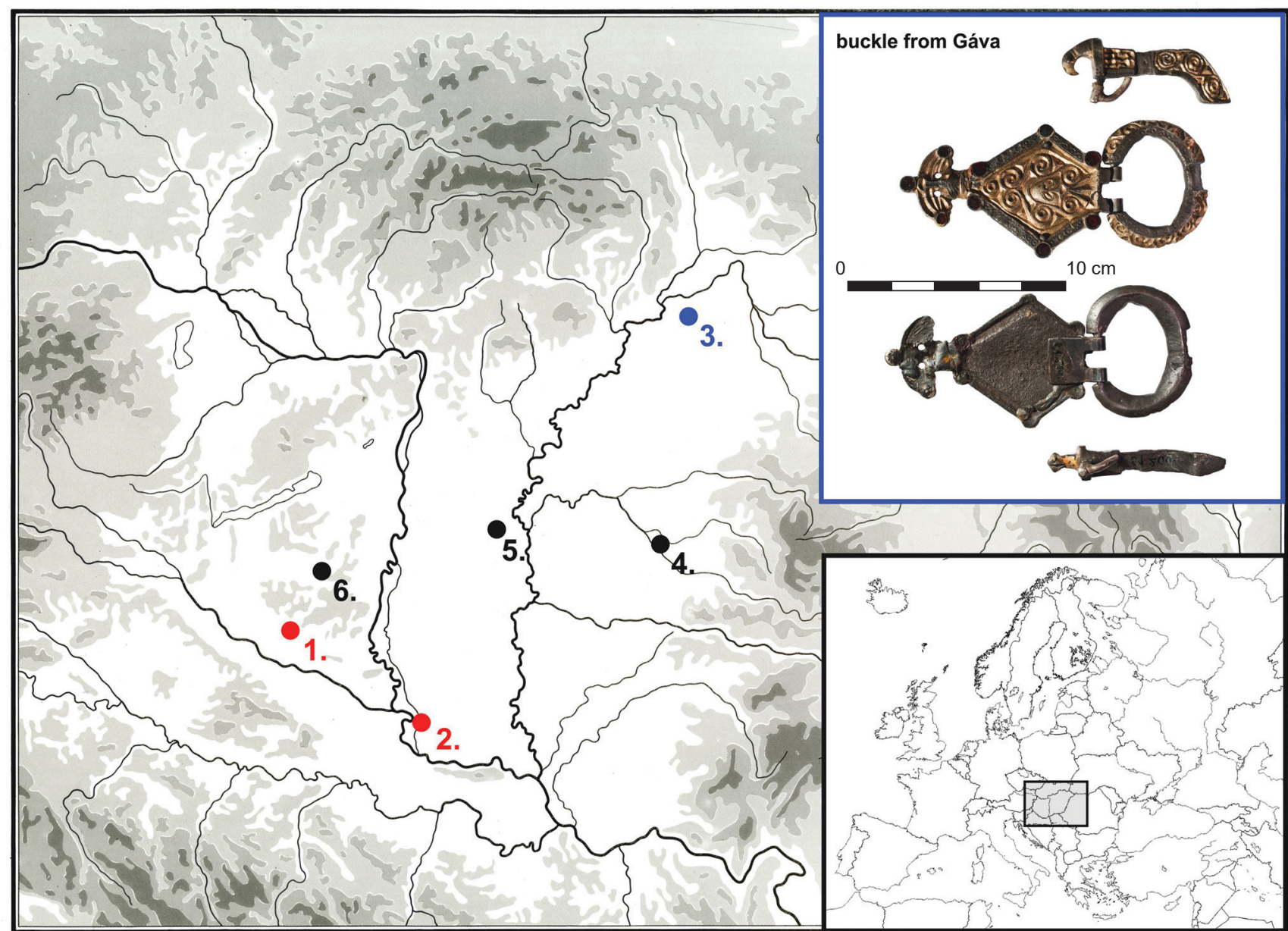

Figure 2. Distribution of cast silver rhomboid belt buckles with polychrome ornamentation in the Middle Danube Region (after Horváth et al., 2013). 1: Zsibót-Domolospuszta; 2: Bácsordas (Karavukovo); 3: Gáva; 4: Gyula; 5: Kiskunfélegyháza; 6: Dombóvár. Red: analysed in the present study; blue: previously analysed (Horváth et al., 2013); black: not yet analysed. Note that an additional buckle analysed in the present study (buckle UP) is from an unknown Hungarian site. 
(hereafter called: buckle ZsD; Baranya county, Hungary; Figure 1A), the second one from Bácsordas (hereafter called: buckle B/K; present-day Karavukovo, West-Bačka District, Serbia; Figure 1B), and the third one from an unknown Hungarian site (hereafter called: buckle UP; Figure 1C). Two of the buckles were unearthed as grave goods (Dombay, 1956; Csallány, 1961; Kiss, 1983), while the third one (buckle UP) is a stray find brought to light in the late $19^{\text {th }}$ century (Hampel, 1905).

These examples have around a dozen close analogies spread around by the Great Migrations $\left(4^{\text {th }}-5^{\text {th }}\right.$ centuries AD) from the Middle Danube Region to Northern Italy and even beyond this main distribution area (Bierbauer, 1975). Only one of them, the buckle from Gáva (Szabolcs-SzatmárBereg county, Hungary; Hampel 1911; Figure 2), had been investigated by archaeometric analysis (Horváth et al., 2013). Using the available data, we are focusing on this buckle as a highlighted item of comparison in our study.

Besides their common material and technological traits, the polychrome animal-style buckles can be classified by ornamentation and style. The items discussed here represent three ornamental and stylistic subgroups. Buckles in the first subgroup (buckles from Bácsordas and Zsibót) are decorated by full-figure representations of birds with their heads bowed down, and a round or drop-shaped garnet inlay in the middle of the front-plate (Figure 1A-B). In the second subgroup (the buckle of unknown provenance), the front-plate is framed with a bird-head frieze. In the middle of the plate, there are garnet inlays in rhomboid shape cloisonné (cellwork) (Figure 1C). The third subgroup (the buckle from Gáva) represents the so-called mask buckles (Maskenschallen) that are characterised by a mask motif and a plate closing in the shape of a wild animal's head, flanked by two bird heads (Figure 2).

These buckles were unique prestige objects of the midto-late $5^{\text {th }}$-century female aristocracy. They were produced and worn in a short period spanning one or two generations. These approximately fifty years represent a transition period in the history of fine metalwork in the Carpathian Basin, between the Hunnic Period (early-to-mid $5^{\text {th }}$ century AD) rich in unique luxury objects and the Langobardic/Gepidic Period (first two thirds of the $6^{\text {th }}$ century AD) in which mass products were more typical. In the Hunnic Period, hammered and soldered gold objects are abundant, whereas the Langobardic/Gepidic Period can be characterised by cast, gilded silver objects (Horváth, 2013). Continuity or changes of the goldsmithing traditions and their organisational background are expected to be manifested on these objects.

The studied buckles were constructed of three, separately cast elements and a hammered piece. The former, i.e., the rhomboid-shaped, highly decorated front-plate (body), the round or oval loop and the strongly profiled tongue were joined to each other by hinge and hook. The fourth element, an undecorated thin back-plate, which might have served to clamp the belt, was fastened by rivets. Among the analysed objects, the back-plate was preserved only on buckle ZsD (Figure 1A). Broken remains of fastening rivets suggest that originally, similar back-plates might have been attached to the rhomboid body of the other buckles too (Figure 1B-C).

The cast parts were manufactured by lost-wax casting, using wax-models (Axboe, 1984). These models were most probably prepared by applying two-part auxiliary moulds, which represented the negative version of the main design: the base form and most of the chip-carving ornamentation. The wax model itself represented the positive, i.e. identical version of the artefact (Genrich, 1977/1978). Further details, such as cavities for inlays, holes for fastening rivets and even some of the punch marks were created at this stage by modelling the wax. The casting resulted in an intermediary design of the artefact; the following post-casting process included the decorative techniques and at the end, the construction of the separately made elements.

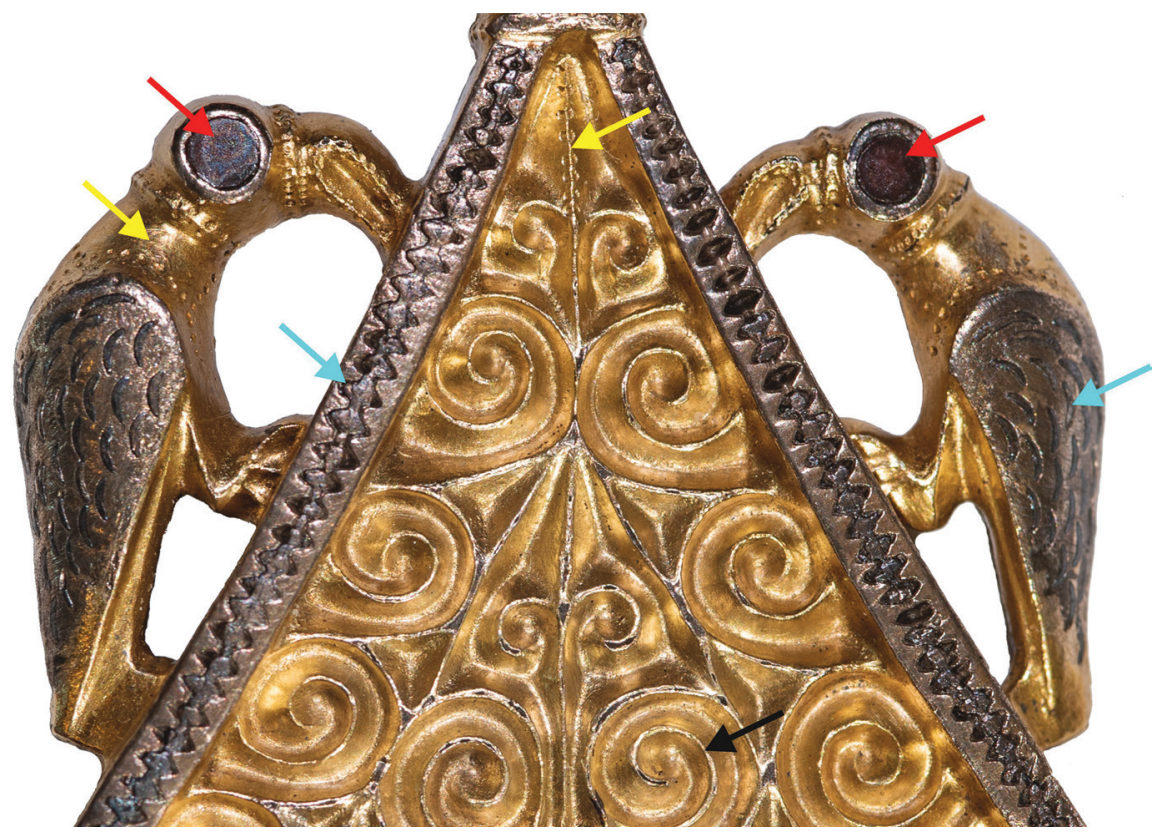

Figure 3. The different decoration techniques used on the buckles resulting in the polychrome effect on the example of buckle B/K: chip-carving (black arrow), gilding (yellow arrows), niello inlaying (blue arrows), garnet inlaying (red arrows) (photo: E. Horváth). 
The characteristic polychrome decoration appears in the colouring effects of the niello- and garnet-inlaid, gilded silver material as well as in the light-shadow effect of the chipcarved ornamentation (Figure 3; Riegl, 1927). Although both niello and garnet inlays occur on fine metalwork in a variety of periods and geographic areas, the combination of these two is a speciality, typical only for the mid-to-late $5^{\text {th }}$-century Middle Danube Region (Nagy, 2007).

Buckles B and ZsD were preserved in their original (in some places incomplete) state during restoration, while the broken hinge of buckle UP was reinforced with a modern supplement (Figure 1C).

Two loose tongues were supposed as potential accessories that belonged to buckle UP; one of these has an ornament in the shape of a bird's head, while the other is decorated with a bird and boar head (Figure 1D-E). As a detailed archaeometric analysis had not been conducted before, it was unclear which of these tongues could originally belong to buckle UP. The tongue with a bird's head has the richest niello decoration. This artefact has a unique ornamentation, as niello mass was applied irregularly on the inner surface of the tongue in addition to the pre-made (punched, carved) depressions (Figure 1C).

\section{Methodology}

In accordance with the artefact protection regulations, only non-destructive and non-invasive methods were allowed to be used. In addition, the size of the objects also limited the range of available methods and analytical equipment that could be used, requiring the use of either handheld equipment and/or instruments with a large sample chamber (Table 2). Furthermore, the surface and accessibility of the measurement points were not always optimal either. The polished surface of the flat garnet inlays resulted in a measurement condition similar to that of polished sections, whereas in the case of metal alloys we had to take into consideration the effect of post-burial alteration (e.g., corrosion processes). Post-burial alteration did not modify the mineralogy of the inlays $(e . g$.,

Table 2. Advantages and limitations of the analytical methods used in the present study. *after Mass and Matsen, 2013; **after Mozgai et al., 2019 a.

\begin{tabular}{|c|c|c|c|}
\hline Analytical method & Application & Pros & Cons \\
\hline hXRF* & $\begin{array}{l}\text { - chemical composition } \\
\text { - simultaneous, multi-element } \\
\text { method } \\
\text { - full concentration range }(Z=12-92) \\
\text { - major, minor, trace elements }\end{array}$ & $\begin{array}{l}\text { - fast } \\
\text { - cheap } \\
\text { - portable } \\
\text { - non-destructive } \\
\text { - no sampling is needed (non- } \\
\text { invasive) } \\
\text { - in most cases, no sample } \\
\text { preparation is needed }\end{array}$ & $\begin{array}{l}\text { - surface method (upper few tens } \\
\text { or hundreds of micrometres) } \\
\text { (inhomogeneities in the objects } \\
\text { due to } e . g ., \text { phase segregation, } \\
\text { corrosion, surface treatments) } \\
\text { - geometric limitations (flat surfaces } \\
\text { are needed) } \\
\text { - standardisation }\end{array}$ \\
\hline SEM-EDX & $\begin{array}{l}\text { - chemical composition and } \\
\text { microtexture } \\
\text { - major and minor elements } \\
\text { - elemental mapping } \\
\text { - imaging at high magnifications } \\
\text { (tool marks, wear traces, etc.) }\end{array}$ & $\begin{array}{l}\text { - fast } \\
\text { - cheap } \\
\text { - small spot size }(1 \mu \mathrm{m}) \\
\text { - non-destructive } \\
\text { - no sampling or special sample } \\
\text { preparation are needed for } \\
\text { conductive materials (non-invasive) }\end{array}$ & $\begin{array}{l}\text { - surface method (upper few } \\
\text { micrometres) (inhomogeneities in } \\
\text { the object and surface treatments) } \\
\text { - geometric limitations (flat surfaces } \\
\text { are needed) } \\
\text { - sample chamber limits the size of } \\
\text { the objects to be analysed } \\
\text { - in case of non-conductive materials } \\
\text { (e.g. garnets, glass inlays) special } \\
\text { sample preparation is needed } \\
\text { - standardisation }\end{array}$ \\
\hline$\mu-\mathrm{XRD}^{* *}$ & $\begin{array}{l}\text { - mineralogical composition (phase } \\
\text { identification) }\end{array}$ & $\begin{array}{l}\text { - fast } \\
\text { - non-destructive } \\
\text { - no sampling or special sample } \\
\text { preparation is needed (non- } \\
\text { invasive) } \\
\text { - spot size: } 10-800 \mu \mathrm{m}\end{array}$ & $\begin{array}{l}\text { - geometric limitations (the object/ } \\
\text { sample may cover certain areas of } \\
\text { the detector, some higher } \mathrm{d}_{\mathrm{hkl}} \text { values } \\
\text { cannot be detected) } \\
\text { - the sample/object is neither } \\
\text { single crystal, nor represent ideal } \\
\text { powder, therefore the measured } \\
\text { peak intensities are increased } \\
\text { or decreased in specific hkl } \\
\text { crystallographic directions due to } \\
\text { preferred orientation } \\
\text { - during data evaluation only peak } \\
\text { positions can be used } \\
\text { - the smaller collimator is used, the } \\
\text { longer measurement time is needed } \\
\text { - sample size is limited }\end{array}$ \\
\hline
\end{tabular}


garnet or niello), only corrosion products of the metal can deposit on their surfaces. However, during the corrosion of precious metal objects (e.g., silver alloys), the base metals (copper, lead) are leached out and silver and gold is enriched towards the surface (Hall, 1961; Lejček et al., 2010).

The buckles were at first thoroughly observed with optical microscopy to characterise the manufacturing techniques, tool marks and garnet inclusions. The chemical composition of the metal alloy and the gilding was analysed by using handheld X-ray fluorescence spectrometry. No surface cleaning was performed prior to the measurements, and we tried to analyse the least corroded parts and as flat surfaces as possible avoiding the contamination/disturbance of gilding and niello inlays. The high value of the objects meant that it was not appropriate to abrade the surface in order to expose the underlying metal over an area of about $3 \mathrm{~mm}$ in diameter $\left(\sim 10 \mathrm{~mm}^{2}\right)$; large enough to match the XRF beam, especially on the highly decorated, clearly visible sides; therefore, the reverse, undecorated sides were measured. Each part of the buckles was analysed at 1-2 points. The hXRF is not an ideal method for analysing niello and garnet inlays. The niello inlays are too small and could not be analysed separately from the metal alloy. In addition, due to limitations of the built-in calibrations of hXRF, the exact composition of the garnet inlays could not be determined either. Therefore, SEM-EDX was used to determine the chemical composition and microtexture of the niello inlays as well as the chemical composition of the garnet inlays.

As garnets are non-conductive materials, a special sample preparation was needed (Bendő et al., 2013). Garnets were first cleaned by ethanol or acetone, after the whole object was wrapped by using aluminium foil and carbon tapes. The foil was pierced above the garnets, leaving a small "window" to be carbon coated. After the coating process, the object is unwrapped making it possible to analyse the garnet and niello inlays and the metal alloy simultaneously. As surface treatments (e.g., paraloid B-72) can highly affect the imaging, the analysed area was thoroughly cleaned with acetone or ethanol. Analyses of non-flat surfaces are even more problematic in the case of SEM-EDX than in the case of hXRF; therefore, we tried to analyse surfaces that are as flat as possible. The carbon coating was removed from the polished garnet surfaces immediately after measurements by using ethanol and gentle manual rubbing.

The mineralogical composition of the niello inlays of the buckles presumed on account of the SEM-EDX results was verified with the use of micro-X-ray diffractometry.

\subsection{Optical microscopy (OM)}

Zeiss SteREO Discovery V12 and V20 modular stereo microscopes and a Zeiss AxioScope A1 upright light microscope equipped with a Zeiss AxioCam MRc5 microscope camera (5MP) were used.

\subsection{Handheld X-ray fluorescence spectrometry (hXRF)}

A SPECTRO xSORT Combi handheld X-ray fluorescence spectrometer was used. Analytical conditions: $15-50 \mathrm{kV}$,
30-120 $\mu \mathrm{A}, \mathrm{Rh}$ anode, Peltier cooling SDD detector, "Light Elements" built-in calibration, $3 \mathrm{~mm}$ measurement area, $30 \mathrm{sec}$ acquisition time. In the case of gilding, the built-in calibration does not calculate the mercury content; therefore, the presence of mercury can only be determined qualitatively based on the hXRF spectra.

\subsection{Scanning electron microscopy with energy- dispersive X-ray spectrometry (SEM-EDX)}

AZEISS EVO 40XVP scanning electron microscope equipped with Oxford Instruments INCA ISIS energy-dispersive X-ray spectrometer (EDS) was used. Analytical conditions: $20 \mathrm{kV}$ accelerating voltage, $6 \mathrm{nA}$ beam current and $30 \mathrm{sec}$ acquisition time. The results were normalised to $100 \mathrm{wt} \%$. During quantitative analysis, the following built-in factory standards were used: $\mathrm{MgO}, \mathrm{Al}_{2} \mathrm{O}_{3}, \mathrm{SiO}_{2}$, wollastonite, $\mathrm{Ti}, \mathrm{Cr}, \mathrm{Mn}, \mathrm{Fe}$, $\mathrm{FeS}_{2}, \mathrm{Cu}, \mathrm{Ag}, \mathrm{Au}$, and HgTe. Each garnet was analysed with at least three (in the case of non-ideal surfaces more than three) point (spots $1 \mu \mathrm{m}$ in diameter) and one area measurements $(200 \mu \mathrm{m} \times 200 \mu \mathrm{m})$. The accuracy of the garnet analyses was determined after Locock (2008). Only the "Superior" and "Excellent" results were used for interpretation. The average of the "Good" and/or "Fair" and/or "Poor" results were used in those cases where no better-quality measurements were received. The "poor-quality" data were treated separately.

\subsection{Micro-X-ray diffractometry ( $\mu$-XRD)}

A RIGAKU D/MAX RAPID II micro-X-ray diffractometer ( $\mu$-XRD), which is a unique combination of a MicroMax-003 third generation microfocus, sealed tube X-ray generator and a curved imaging plate detector, was used. The diffractometer was operated with $\mathrm{CuK}_{\alpha}$ radiation generated at $50 \mathrm{kV}$ and $0.6 \mathrm{~mA}$. A collimator 100 micrometres in diameter and 20 min measurement time was used for analyses. A built-in CCD camera was used to select the measurement areas. A laser scanning readout system reads the imaging plate detector in about 1 min. RIGAKU 2D Data Processing software 2DP was used to record the diffraction image from the laser readout. For each XRD pattern, the interpretable $2 \Theta$ region was selected manually. RIGAKU PDXL 1.8 integrated X-ray powder diffraction software was used for data processing.

\section{Results}

\subsection{Silver alloy composition}

The buckles were manufactured from high-quality silver $(>80 \mathrm{wt} \%$ ), intentionally alloyed with copper (Table 3; Figure 4). Beside the typical minor and trace elements (gold, lead, and bismuth), zinc was detected in each of the buckles.

The different parts (front-plate, loop, tongue, and backplate) of buckle ZsD (Figure 1A) were manufactured from different silver alloys. The back-plate has the highest (95.4 wt\%), while the loop has the lowest silver content $(87.4 \mathrm{wt} \%)$. The gold, lead and zinc contents also vary in the different parts. Buckle ZsD has the lowest zinc (0-0.6 wt\%) 


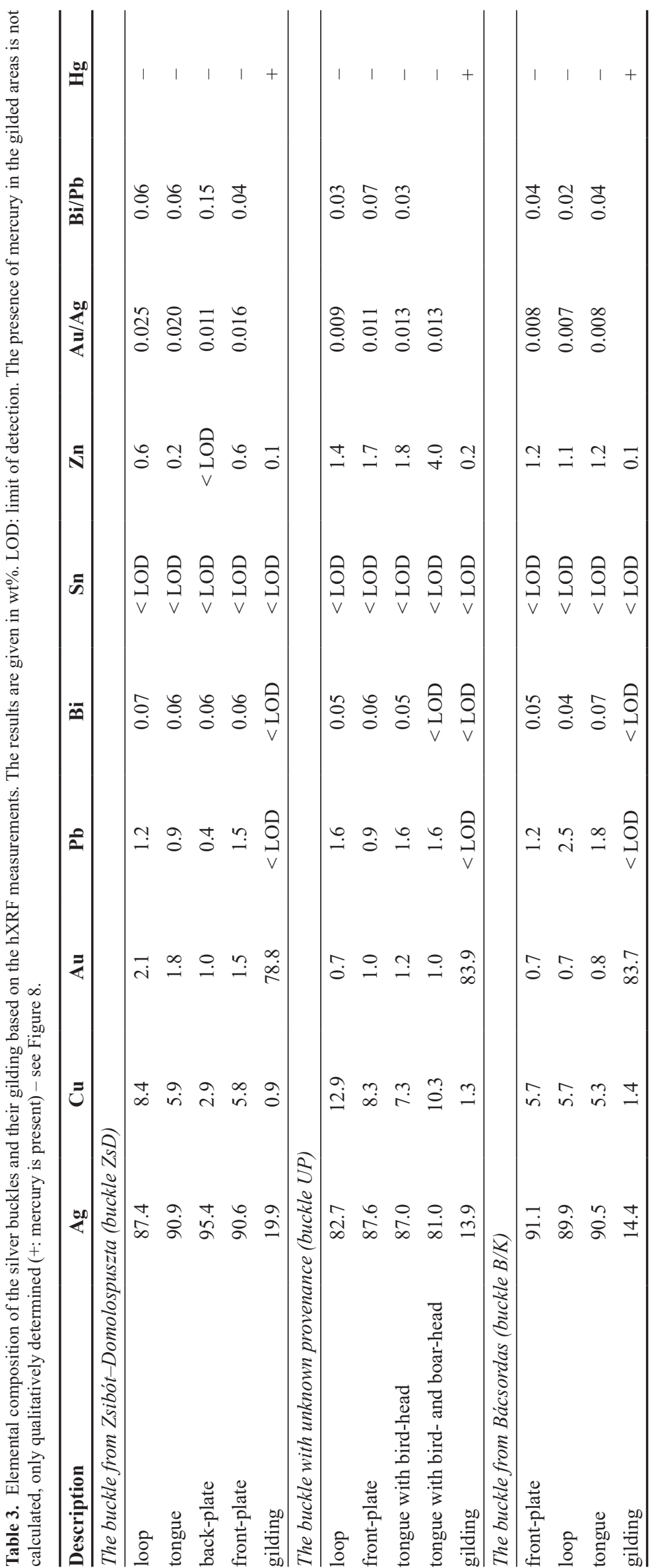



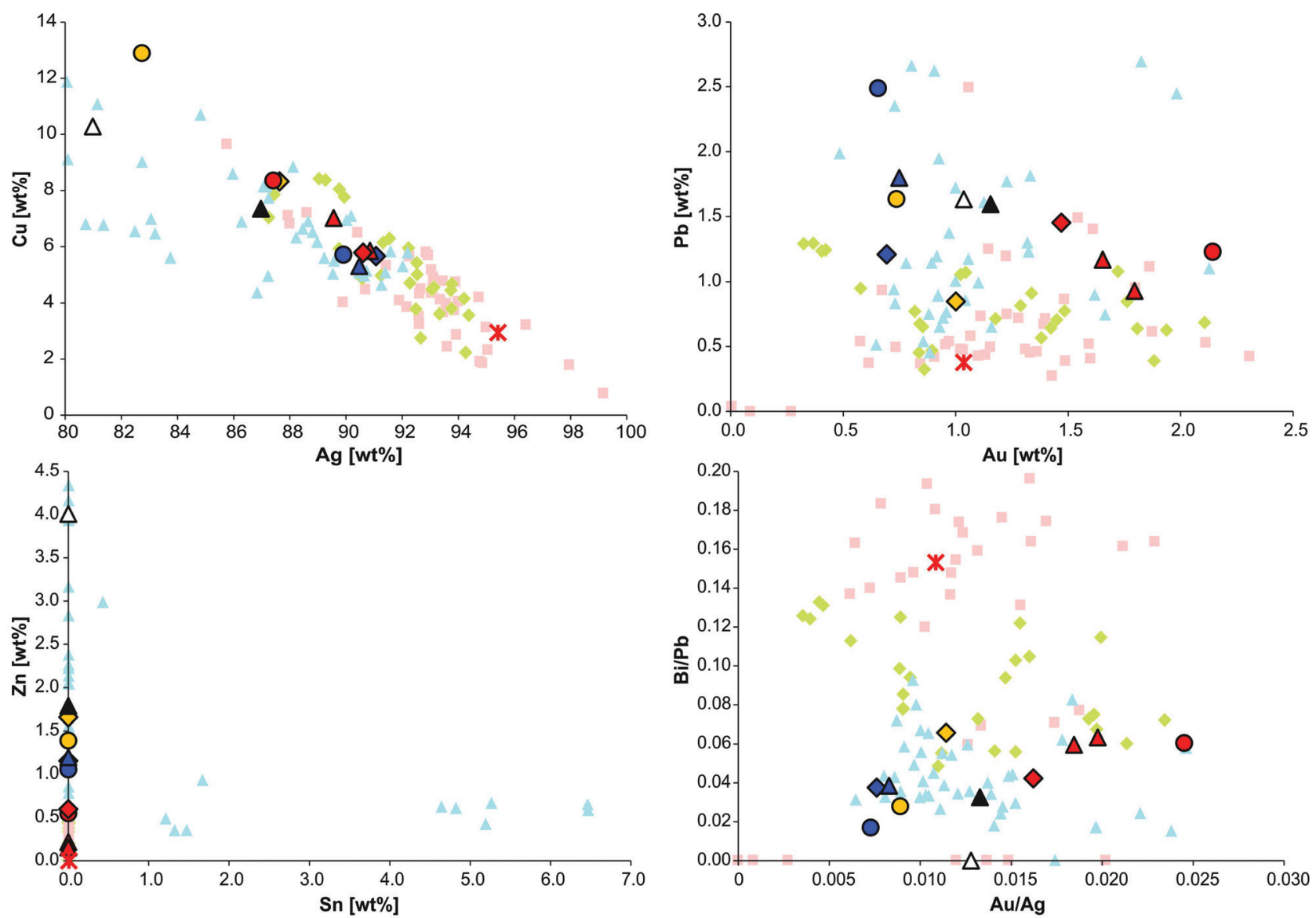

buckle B/K buckle UP buckle ZsD

$\diamond$ plate Oloop $\Delta$ tongue $\boldsymbol{*}$ back-plate

early $5^{\text {th }} c . A D \diamond$ mid- $5^{\text {th }} c . A D \triangle$ late $5^{\text {th }}$ c. $A D$

Figure 4. Composition of the three buckles based on the hXRF measurements. Black triangle: tongue with a bird's head of the buckle UP, white triangle: tongue with a bird and boar heads of the buckle UP. Elemental composition of silver objects from the $5^{\text {th }}$ century AD is depicted for comparison (unpublished data).

and highest gold content (1.0-2.1 wt \%) among the buckles.

The different parts (front-plate, loop, and tongue) of buckle $B / K$ (Figure $1 \mathrm{~B}$ ) were manufactured from a rather similar silver alloy in terms of its silver (89.9-91.1 wt\%), copper $(5.3-5.7 \mathrm{wt} \%)$, and gold $(0.7 \mathrm{wt} \%)$ content. This artefact has the lowest gold content among the buckles. In contrast, there is a considerable difference between its parts in terms of lead content: the loop has the highest $(2.5 \mathrm{wt} \%)$, while the frontplate has the lowest $(1.2 \mathrm{wt} \%$ ) lead content. The zinc content is $1.1-1.2 \mathrm{wt}^{0} \%$.

The different parts (front-plate, loop and tongues) of buckle UP (Figure 1C) were manufactured from different low quality silver alloys $(81.0-87.6 \mathrm{wt} \% \mathrm{Ag})$. The gold and lead contents of its parts differ markedly $(0.7-1.2 \mathrm{wt} \% \mathrm{Au}$; $0.9-1.6 \mathrm{wt} \% \mathrm{~Pb})$. This buckle has the highest zinc content among the analysed buckles (1.4-4.0 wt\%). The composition of the tongue with the bird's head is similar to that of the front-plate of the artefact, while the tongue decorated with the bird and boar heads has the lowest silver $(81.0 \mathrm{wt} \%)$ and highest zinc $(4.0 \mathrm{wt} \%)$ content among the objects.

\subsection{Niello inlays}

The buckles were extensively decorated with niello inlays. The design of the niello decoration usually shows coherency on buckles $\mathrm{ZsB}$ and $\mathrm{B} / \mathrm{K}$. In the case of buckle UP, the ornamentation is mostly smooth and regular on the loop and the tongue, while on the plate it is conceptually defective and deteriorated in several places.

The elemental composition of the niello inlays is very heterogeneous $(29.8-64.2 \mathrm{at} \% \mathrm{Cu})$, even within a single object. It is composed of different silver-copper sulphides with different $\mathrm{Ag}: \mathrm{Cu}$ ratios ranging from 1:1 to pure copper sulphide (Table 4; Figure 5). The surface of the niello inlays is not even and flat, indicating that the niello inlays were not polished after application (Figure 6A-B). The microtexture of the niello shows inhomogeneities: lighter and darker phases alternate with each other in the BSE images. In the niello inlays of buckles ZsD and UP the irregular darker phases a few tens of micrometres in size are Ag-Cu sulphides or $\mathrm{Cu}$-sulphides, while lighter phases are metallic silvercopper alloy (irregular shaped, a few tens of micrometres in size) or contamination with mercury and gold (narrow strings along the grain boundaries, a few micrometres in size) (Figure $6 \mathrm{C}-\mathrm{D}$ ). In the niello of buckle $\mathrm{B} / \mathrm{K}$ the irregular darker phases a few hundreds of micrometres in size are Ag$\mathrm{Cu}$ sulphides with higher copper content, while the irregular, string-like lighter phases a few tens of micrometres in size are $\mathrm{Ag}-\mathrm{Cu}$ sulphides with higher silver content (Figure 6E). 


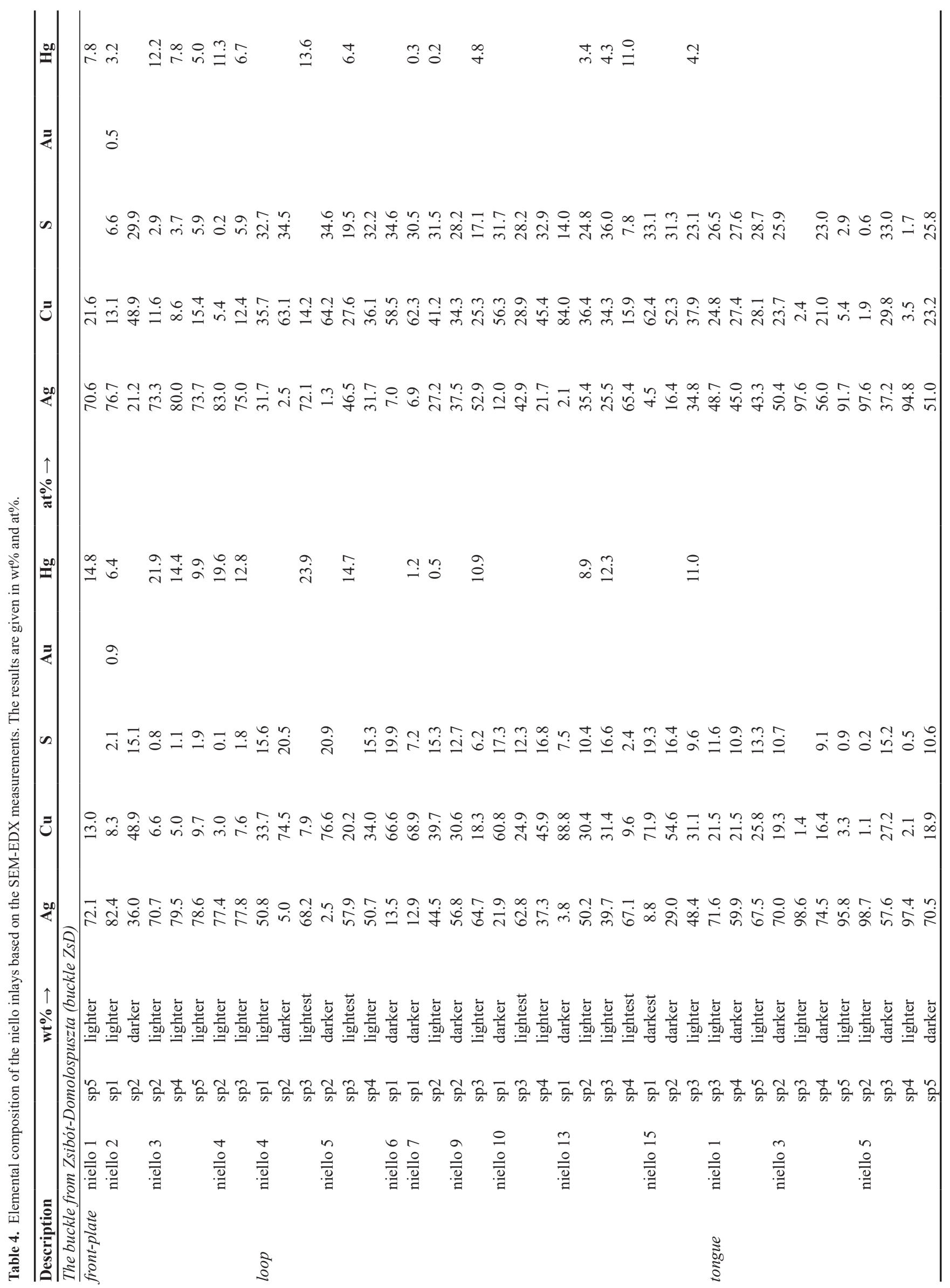




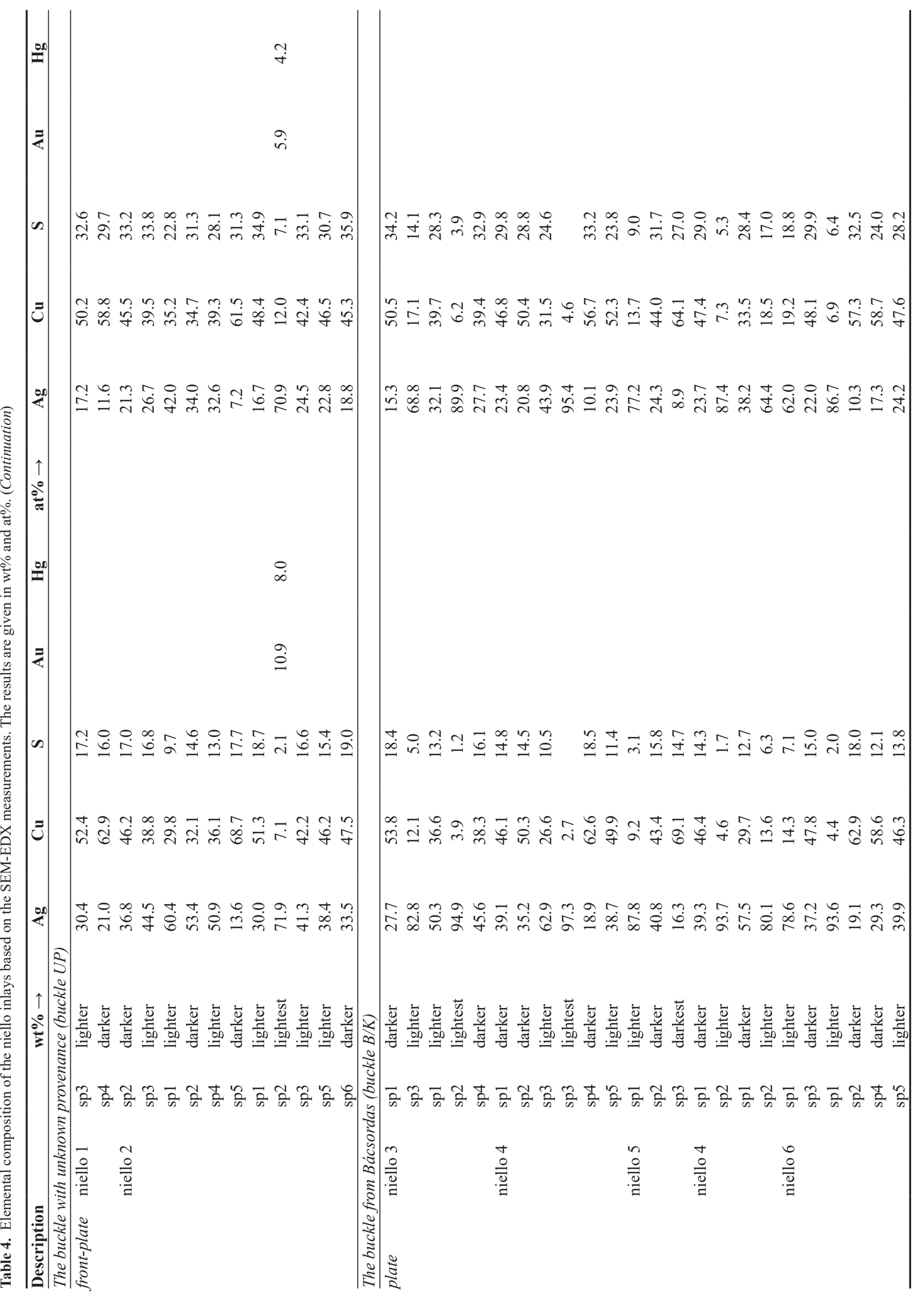




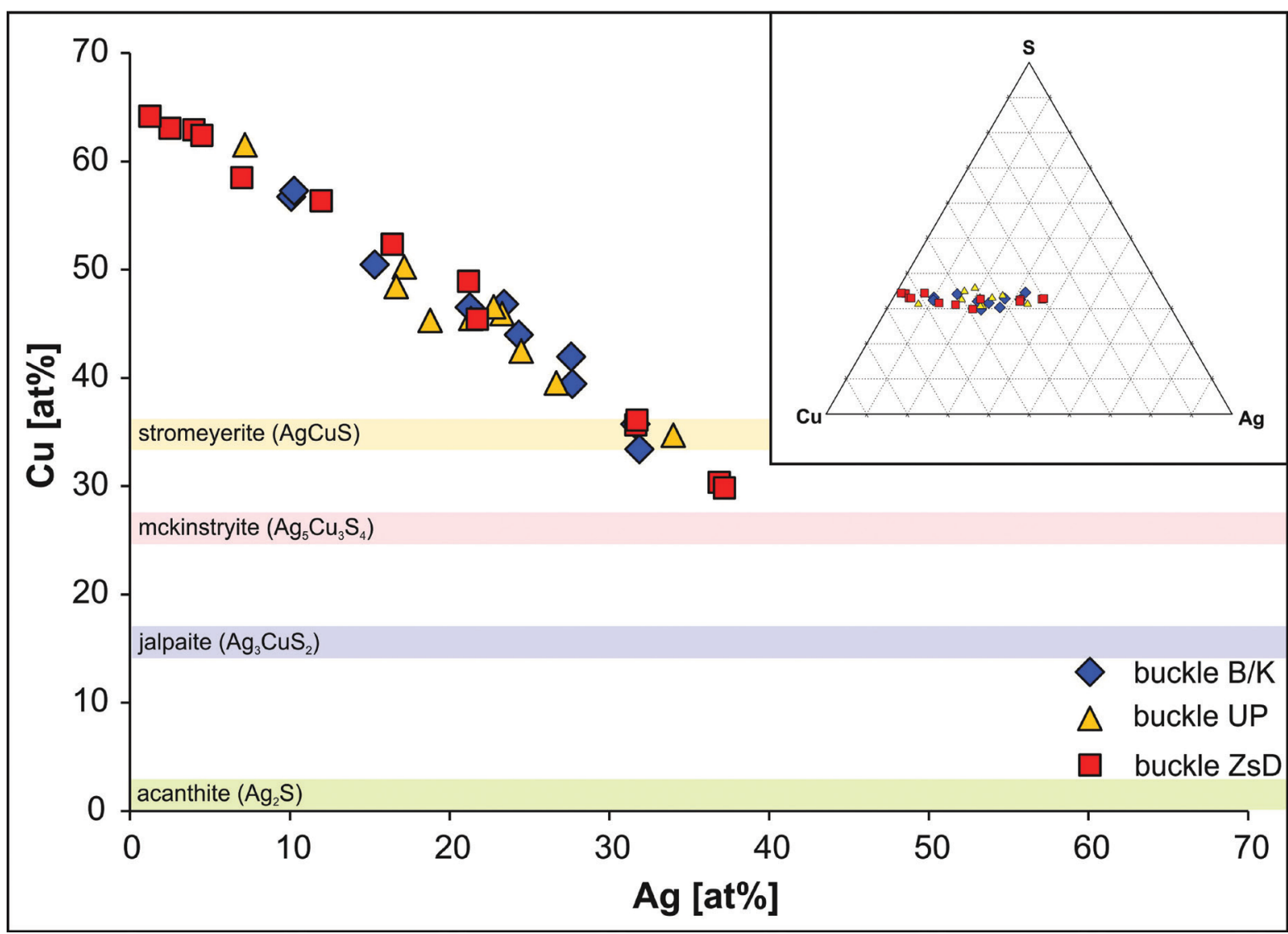

Figure 5. Composition of the niello inlays of the buckles based on SEM-EDX measurements. Chemical ranges for different silver-copper sulphides are based on Grybeck and Finney (1968) for jalpaite $\left(\mathrm{Ag}_{1.55} \mathrm{Cu}_{0.45} \mathrm{~S}-\mathrm{Ag}_{1.5} \mathrm{Cu}_{0.5} \mathrm{~S}\right)$; Skinner et al. (1966) and Kolitsch (2010) for mckinstryite $\left(\mathrm{Ag}_{1.18} \mathrm{Cu}_{0.82} \mathrm{~S}\right.$ $\left.\mathrm{Ag}_{1.25} \mathrm{Cu}_{0.75} \mathrm{~S}\right)$, and Frueh (1955) and Tokuhara et al. (2009) for stromeyerite $\left(\mathrm{Ag}_{0.9} \mathrm{Cu}_{1.1} \mathrm{~S}-\mathrm{Ag}_{1.0} \mathrm{Cu}_{1.0} \mathrm{~S}\right)$, respectively.

The results of the $\mu$-XRD measurements proved the presence of stromeyerite $(\mathrm{AgCuS})$, digenite $\left(\mathrm{Cu}_{9} \mathrm{~S}_{5}\right)$ and metallic silver in the niello inlays of the buckles (Figure 7A-C). The niello inlay of the tongue with bird and boar heads was studied only by using $\mu$-XRD and revealed that the niello inlay is composed not only of stromeyerite and metallic silver, but also jalpaite $\left(\mathrm{Ag}_{3} \mathrm{CuS}_{4}\right)$ and acanthite $\left(\mathrm{Ag}_{2} \mathrm{~S}\right)$ (Figure 7D).

\subsection{Gilding}

The buckles were extensively gilded. The gold content of the gilded areas is around or above $80 \mathrm{wt} \%$ on each buckle based on the hXRF measurements (Table 3), indicating a rather thick gilding. The thickness of the gilding is estimated to be around several tens of micrometres based on BSE images (Figure 6F). Mercury was detected in the gilded areas by hXRF and SEM-EDX measurements as well (Figure 8).

\subsection{Garnet inlays}

Red garnet inlays played an important role in the decoration of the buckles. Highlighting the eyes and mouth of the bird and boar figures, they are contrasting with the colours of precious metals and niello (Figure 3). The prevailing shape of the garnet slabs is flat and round, although some triangular, rectangular, lunula- and drop-shaped pieces are also present.
As these pieces are mounted, it proved impossible to analyse the full range of mineral inclusions in the individual garnets. This limited access is a general problem; loose, unmounted pieces are very rarely found (Horváth and Bendö, 2011). The detected inclusions have been identified based on their morphology. Most of these are accessory minerals (e.g., rutile needles, ilmenite plates, isometric zircon, and xenomorph quartz crystals) that are not indicators for the source rocks. From this aspect, kyanite crystals and curved needles of sillimanite, detected in a group of the slabs, are of greater importance since they indicate medium- to highgrade metamorphism at medium pressure (Figure 9A-B) (Spear, 1995). One typical combination of inclusions occurs extensively in the garnets of buckle ZsD: these are extremely fine, wavy rays of fluid inclusions accompanied by ilmenite plates (Figure 9C-D). Another specific type of inclusion is the large, clear apatite crystals in the garnets of the tongue with the bird and boar heads, belonging to buckle UP.

From among the 55 garnet inlays preserved in the settings of the buckles, 45 pieces were analysed by SEM-EDX. Based on the chemistry, the garnets used for inlays are from the pyralspite (pyrop-almandine-spessartine) series, namely almandine with varying $\mathrm{Ca}, \mathrm{Mg}$ and $\mathrm{Fe}$ contents (Figure 10). Some garnets of buckle $\mathrm{B} / \mathrm{K}$ exhibit higher $\mathrm{Mg}$ concentrations, often referred to as intermediate 

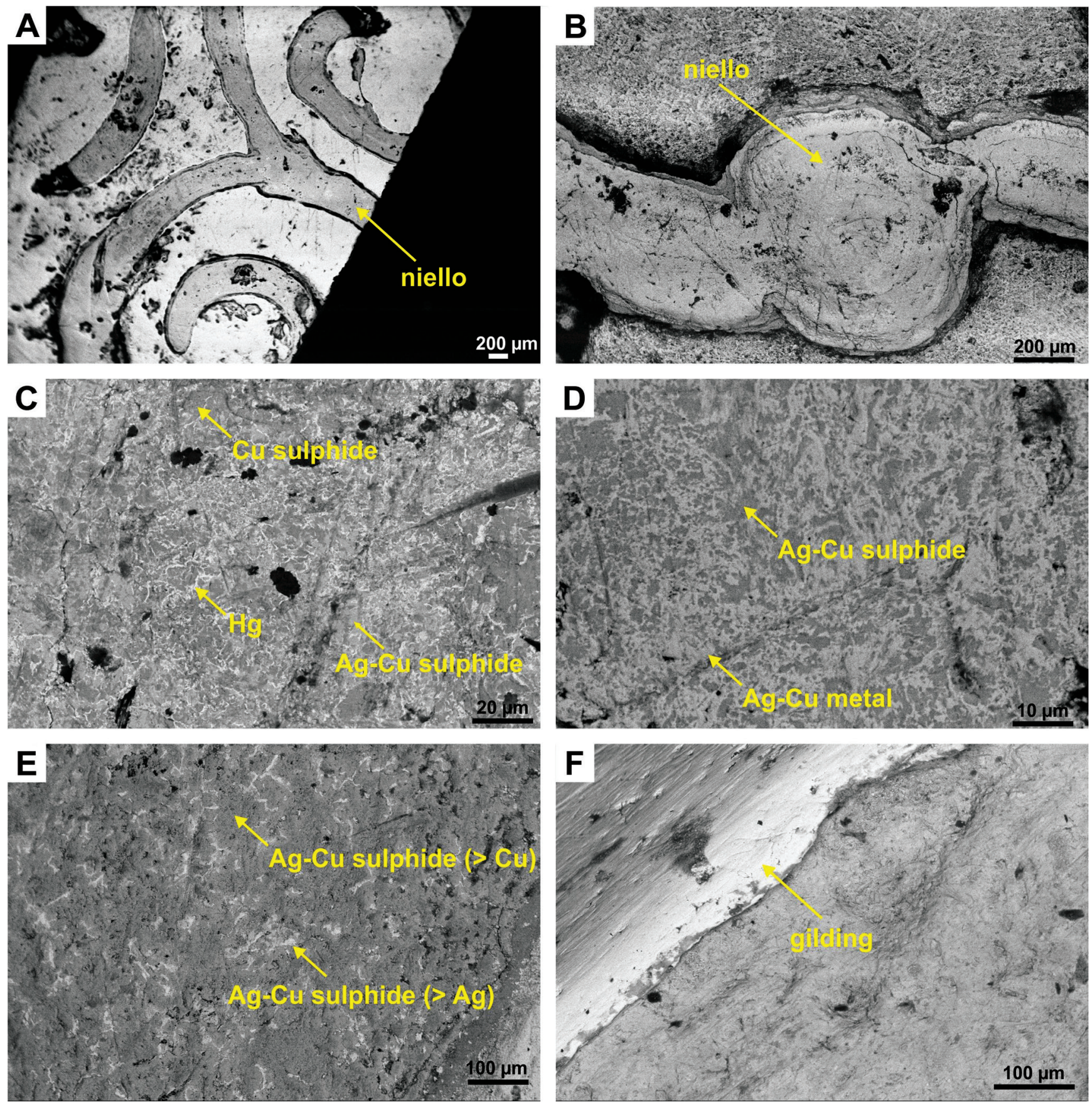

Figure 6. Backscattered electron images of the niello inlays and gilding of the buckles. A-B: niello inlays were put in previously carved recesses, the surface of the niello is not flat, polished or even on buckles $\mathrm{B} / \mathrm{K}$ and $\mathrm{ZsD}$; $\mathrm{C}$ : heterogeneous niello of the loop of buckle ZsD; D: heterogeneous niello of the tongue of buckle ZsD; E: niello inlay of buckle B/K; F: rather thick gilding on the plate of buckle ZsD.

pyrope-almandine crystals (Gilg et al., 2010). No ugrandite (uvarovite-grossular-andradite) series garnet was identified on the buckles.

\section{Discussion}

\subsection{Silver alloy composition}

The buckles were manufactured from relatively high-quality silver (82.7-95.4 wt\% Ag), which corresponds well with the general trend that during the $5^{\text {th }}$-century $\mathrm{AD}$ a gradual debasement of silver alloys occurred towards the end of the century (Figure 4) (Horváth et al., 2019; Mozgai et al., $2019 \mathrm{~b}$ ). The beginning of the $5^{\text {th }}$ century AD is characterised with high-quality silver alloys with low $\mathrm{Au}, \mathrm{Pb}$ and $\mathrm{Zn}$ and varying $\mathrm{Bi}$ content similar to late Roman silver alloys (Hughes and Hall, 1979; Lang et al., 1984; Feugère, 1988; Lang, 2002; Cowell and Hook, 2010; Hook and Callewaert, 2013; Doračić et al., 2015; Lang and Hughes, 2016; Greiff, 2017; Mozgai et al., 2017; Vulić et al., 2017; Mozgai et al., 


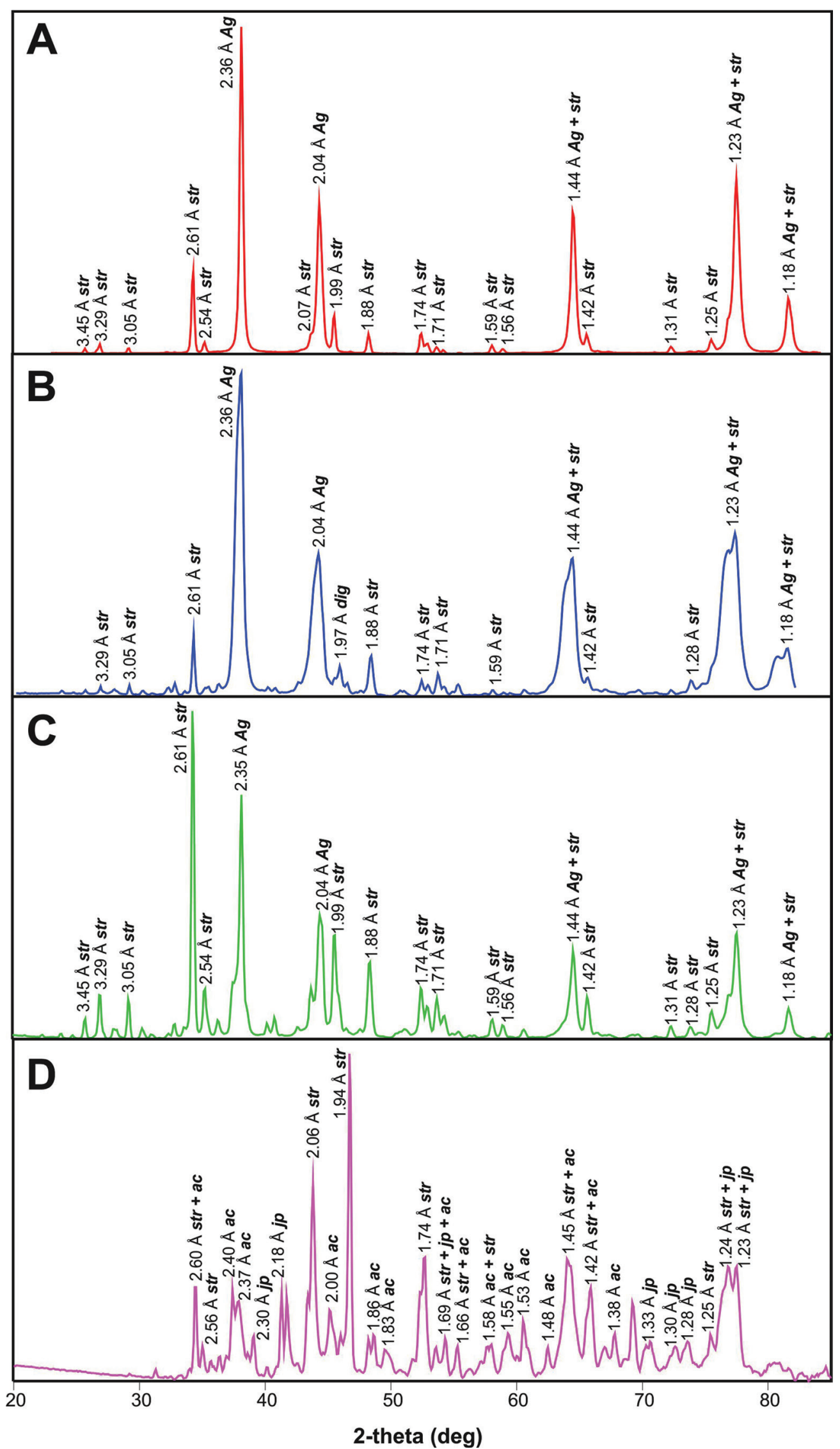

Figure 7. Typical $\mu$-XRD patterns of the niello from the buckles. A: tongue of buckle ZsD; B: loop of buckle ZsD; C: tongue with a bird's head of buckle UP; D: tongue with a bird and boar heads of buckle UP. Abbreviations: ac = acanthite (JCPDS 14-0072); jp = jalpaite (JCPDS 12-0207); str = stromeyerite (JCPDS 75-0890); dig = digenite (JCPDS 84-1770); Ag = metallic silver (JCPDS 87-0598). 


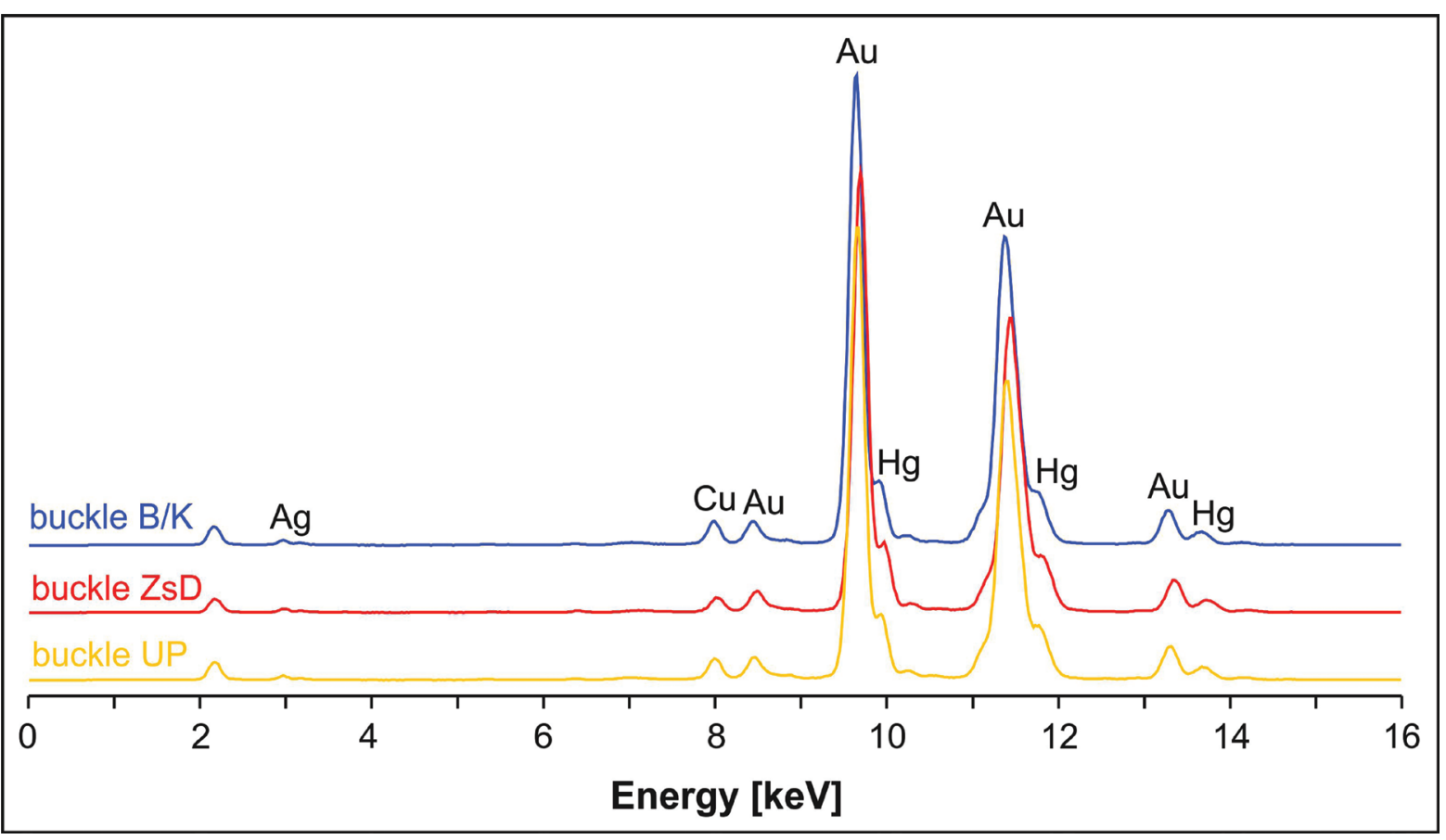

Figure 8. Typical XRF spectra of the gilded areas of the buckles.

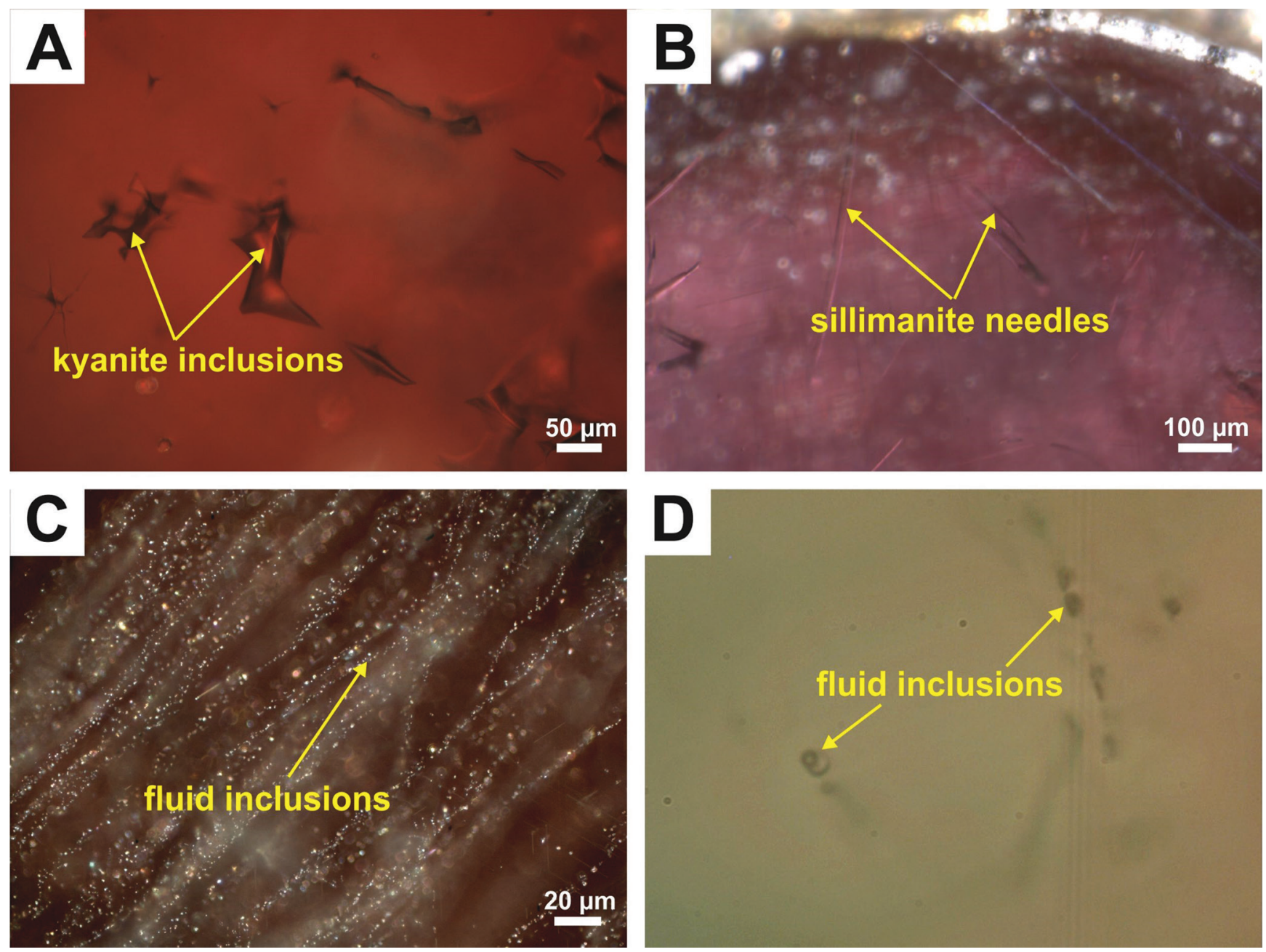

Figure 9. Typical mineral inclusions in the garnets of the buckles. A: buckle B/K; B: buckle UP; C-D: buckle ZsD (photos: E. Horváth). 


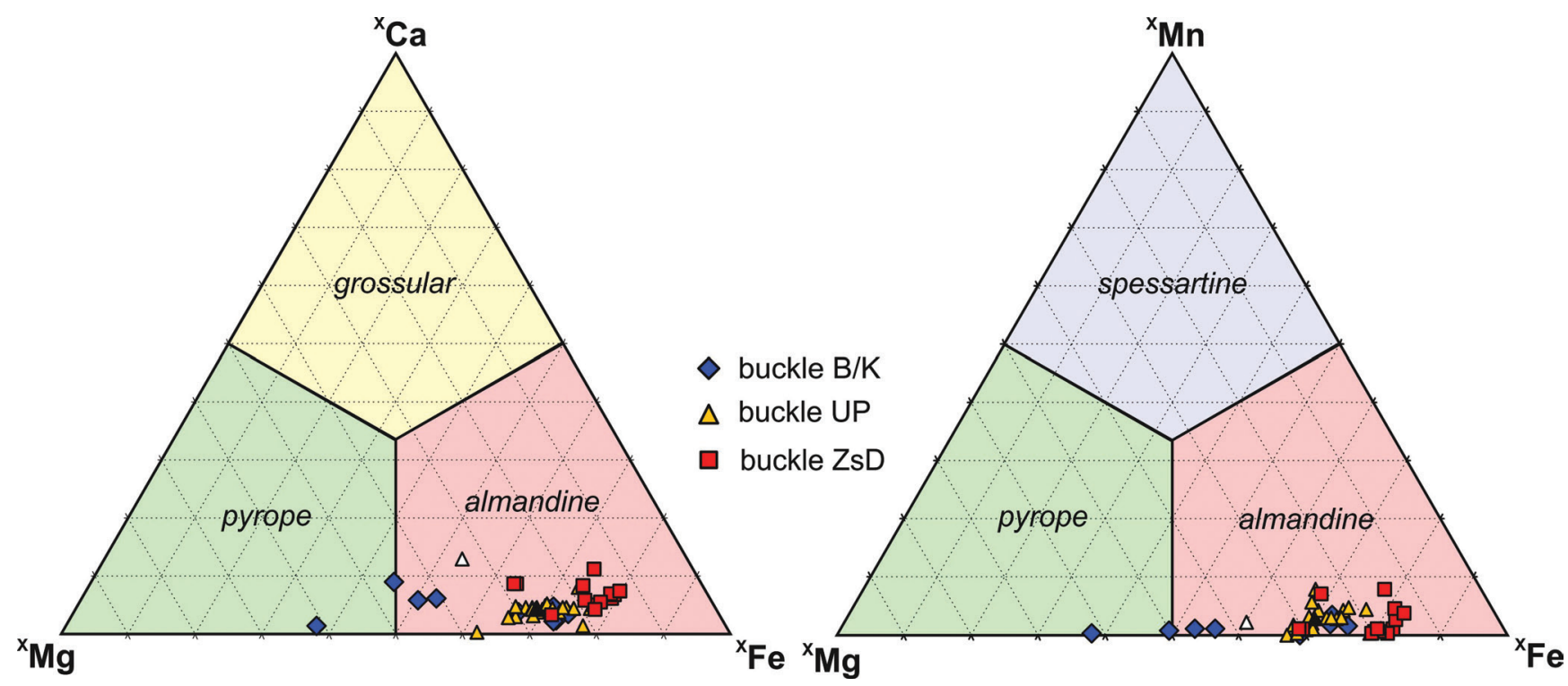

Figure 10. Ternary plots showing the composition of the garnets from the buckles based on the cation occupancy of the $\mathrm{X}$ site in the garnet structure calculated from the SEM-EDX data (after Grew et al., 2013). Black triangle: tongue with a bird's head of buckle UP, white triangle: tongue with a bird and boar heads of buckle UP.

2020; Mozgai et al. 2021). In contrast, lower quality silver alloys with high $\mathrm{Cu}, \mathrm{Pb}, \mathrm{Zn}$ and $\mathrm{Sn}$ content, reaching even the 1:1 Ag:Cu ratio (Figure 4), are more typical for the end of the $5^{\text {th }}$ century AD (Horváth et al., 2019; Mozgai et al., 2019b).

Pure silver is too soft for making silver objects of use, because they would have a tendency to suffer dents, and bend and wear easily. The most common alloying metal in silver is copper, which improves the mechanical properties of soft silver (e.g., increases strength and durability). During silver extraction, the copper content could be reduced to even $0.2-1 \%$; therefore, higher copper concentration indicates intentional alloying (Hughes and Hall, 1979).

The measured elements other than silver and copper are naturally occurring, unintentionally or intentionally added elements, deriving from the silver ore or from the copper (bronze, brass) used for alloying (Hughes and Hall, 1979).

In antiquity, the main source of silver was silverbearing lead ores (Tylecote, 1962; Forbes, 1971). The silver ores were roasted, melted and cupelled during silver extraction. Cupellation separates silver very efficiently from impurities (mainly from antimony, arsenic, tin, iron, and zinc; less well from copper, gold and bismuth). The volatile elements (antimony, arsenic, mercury, tin and zinc) disappear from molten silver during cupellation (Pernicka, 2014; L'Héritier et al., 2015). Therefore, the elevated zinc content $(0.2-4.0 \mathrm{wt} \% \mathrm{Zn})$ of the buckles indicates that not pure copper, but brass was added to the silver as an alloying metal. The most important benefit of alloying is that it lowers the melting point. The more copper is added to molten silver; the more yellowish tint the alloy will have. This can be overcome by adding zinc to the alloy, which will act as a sort of "whitener" upgrading the colour (Greiff, 2012). The addition of zinc also prevents molten silver from oxidation and bubbling, and enhances tarnish-proofness resulting in a much nicer polish (Greiff, 2012). The addition of tin has a similar effect on colour and tarnish-proofness. Moreover, it enhances ductility making tin-enriched silver alloys more ideal for sheet production (Greiff, 2012). It is uncertain whether $5^{\text {th }}$-century goldsmiths were aware of these effects and intentionally alloyed the silver with $\mathrm{Zn}$ (or $\mathrm{Sn}$ ), beside copper.

If silver originates from silver-bearing lead ores (galena, anglesite or cerussite), the lead content in the silver alloy ranges between $0.001 \%$ and 3\% (Moorey, 1985). The lead content of cupelled silver is typically between 0.5 and $1.2 \mathrm{wt} \%$ (Greiff, 2012). The lead content of the buckles shows generally higher concentrations $(0.4-2.8 \mathrm{wt} \% \mathrm{~Pb})$, indicating that leaded copper or leaded brass was used for alloying.

Bismuth is a good geochemical indicator that helps identifying the provenance of silver objects, as its concentration remains relatively constant during cupellation (Pernicka and Bachmann, 1983; Pernicka, 2014; L’Héritier et al., 2015). Based on experiments, bismuth is oxidised only in the very last stages of cupellation and, therefore, bismuth in silver objects is correlated with the degree of cupellation. However, the final $\mathrm{Bi} / \mathrm{Pb}$ ratio of the cupelled silver depends on the initial $\mathrm{Bi}$ content of the silver-bearing lead ores (L'Héritier et al., 2015). The $\mathrm{Bi} / \mathrm{Pb}$ ratio of the buckles is rather low and consistent, except the back-plate of buckle ZsD (Figure 4), which is typical for the silver alloys from the middle and end of the $5^{\text {th }}$ century AD (Horváth et al., 2019; Mozgai et al., 2019 b), in contrast with silver alloys from the beginning of the $5^{\text {th }}$ century $\mathrm{AD}$ and from late Roman times. The latter usually have more varied $\mathrm{Bi} / \mathrm{Pb}$ ratios, indicating the use of silver from different ore sources (Cowell and Hook, 2010; Doračić et al., 2015; Greiff, 2017; Mozgai et al., 2017; Vulić et al., 2017; Mozgai et al., 2020; Mozgai et al. 2021). The more constant $\mathrm{Bi} / \mathrm{Pb}$ ratio in silver objects from the middle and end of the 


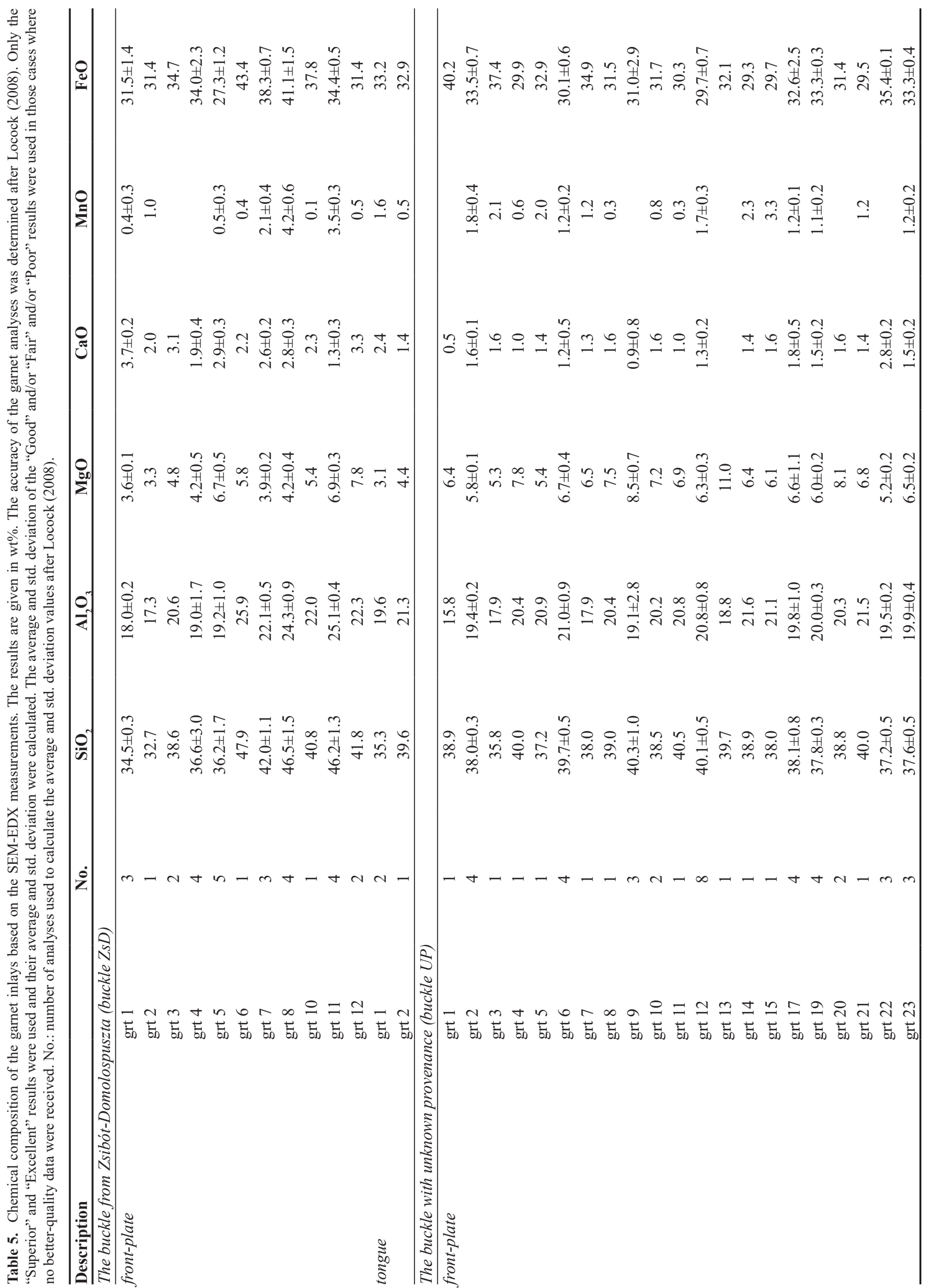




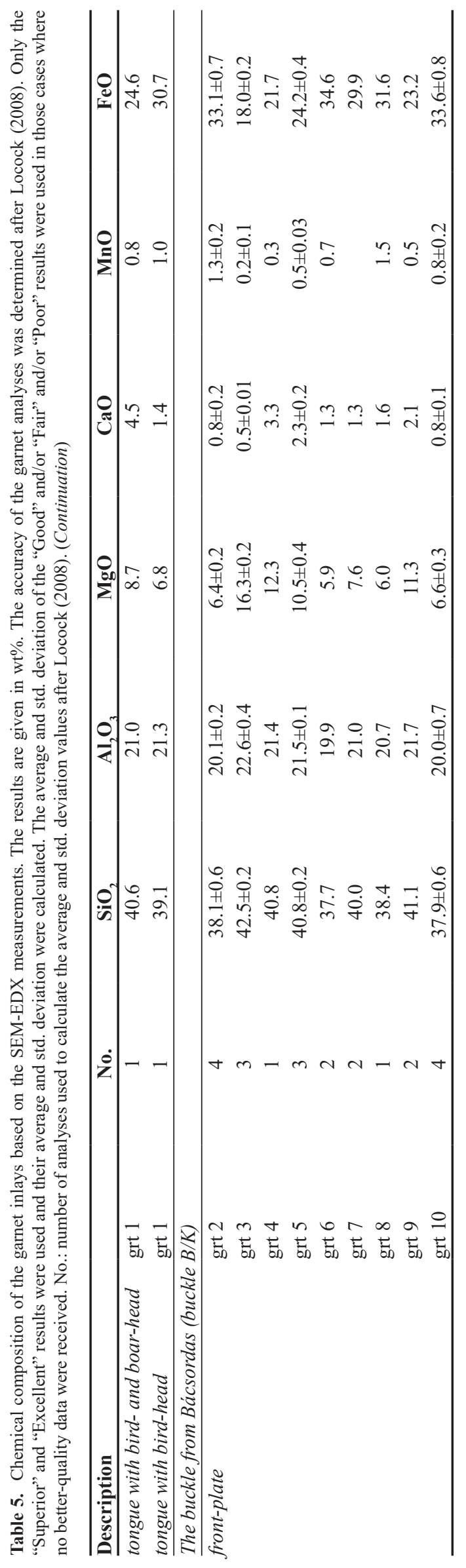

$5^{\text {th }}$ century AD may be the result of gradual recycling and mixing of different silver alloys, and therefore, in our case, the $\mathrm{Bi} / \mathrm{Pb}$ ratio is not indicative of provenance.

Gold is completely miscible with silver. During metallurgical processes, the gold content of the silver does not change radically (L'Héritier et al., 2015), and as a consequence, the $\mathrm{Au} / \mathrm{Ag}$ ratio remains constant during cupellation (Pernicka, 2014). The buckles show elevated concentrations of gold $(0.7-2.1 \mathrm{wt} \% \mathrm{Au})$, and, as a result, elevated $\mathrm{Au} / \mathrm{Ag}$ ratios (Figure 4). Various interpretations are possible for higher gold concentrations, e.g., remnants of former gilding, the re-use of scrap gilded silver, or the use of gold-silver ores. In the case of buckles, as recycling was proven by other elements as well, it is safe to say that most probably re-used scrap gilded silver was utilised for manufacturing.

The polychrome animal-style silver buckle from Gáva, previously analysed by Horváth et al. (2013), exhibits slightly lower silver (81.5-82.5 wt\%) and higher lead content $(1.9-2.8 \mathrm{wt} \%)$ than the three buckles discussed in this study. The gold content is, however, similar $(0.8-1.0 \mathrm{wt} \%)$. The main difference is that beside zinc (1.9-2.5 wt \%), elevated tin content (5.5-5.8 wt\%) was also detected in the buckle from Gáva, indicating the use of leaded bronze or gunmetal for alloying.

The differences in the elemental composition of the silver alloys indicate the use of different silver alloys in manufacture. The shortage of raw materials towards the end of the $5^{\text {th }}$ century $\mathrm{AD}$ resulted in the re-use and recycling of more diverse materials. Furthermore, the differences in alloy compositions, even within one single object, indicate that there was no conscious or standardised alloying practice adopted by $5^{\text {th }}$-century $\mathrm{AD}$ goldsmiths.

The only undecorated back-plate that was analysed in the study, used for fastening the strap/belt, belongs to buckle ZsD. Its composition differs completely from the other parts of the buckle and shows similarities to late Roman silver alloys (high silver content, relatively low gold, lead and copper content, and no zinc) (Figure 4). It may have been manufactured by melting Roman silver objects directly, without further alloying.

\subsection{Niello inlays}

The bluish-black niello has been widely used to decorate silver, gold and copper-based alloy objects. Chemically, niello is composed of the sulphide of one or more metals, fused or inlaid into a recess carved into the metal surface. The composition of niello changed over the course of time depending on what type of metal it decorated (Rosenberg, 1908; Moss, 1953; Dennis, 1979; Newman et al., 1982; La Niece, 1983; Oddy et al., 1983; Schweizer, 1993; Northover and La Niece, 2009).

Niello technique was much used in the early Middle Ages, but there are still uncertainties concerning the niello technique (exact composition, preparation and application) used in this particular period. It has been widely accepted that during the Roman period niello was generally composed 
of the sulphide of only one metal, namely the same as the metal it decorates: silver sulphide (acanthite $\mathrm{Ag}_{2} \mathrm{~S}$ ) for silver objects and mixtures of copper sulphides (chalcocite $\mathrm{Cu}_{2} \mathrm{~S}$, digenite $\mathrm{Cu}_{9} \mathrm{~S}_{5}$ and covellite $\mathrm{CuS}$ ) for copper-based alloy objects. Intentional use of binary silver-copper sulphide niello (stromeyerite $\mathrm{AgCuS}$ ) is assumed to have started only at the end of the $5^{\text {th }}$ century AD (Moss, 1953; Dennis, 1979; Newman et al., 1982; La Niece, 1983; Oddy et al., 1983; Schweizer, 1993; Northover and La Niece, 2009). Recent studies have proved that silver-copper sulphide niello (reaching the composition of stromeyerite) was already being used in Roman times (Mozgai et al., 2019c).

The studied buckles were decorated with silver-copper sulphides of various $\mathrm{Cu}$ content (29.8-64.2 wt\%), and the $\mu$-XRD measurements proved the presence of stromeyerite $(\mathrm{AgCuS})$, digenite $\left(\mathrm{Cu}_{9} \mathrm{~S}_{5}\right)$ and metallic silver. The niello inlays of the buckle from Gáva are also silver-copper sulphides with sporadically detected lead and tin contents, which was interpreted as niello prepared from debased silver (Horváth et al., 2013). Previous studies on niello-inlaid objects from the $5^{\text {th }}$ century AD proved the presence of mixed silver-copper sulphides (La Niece, 1983; Craddock et al., 2010; Horváth et al., 2013), but niello inlays with very high copper content on silver objects, reaching even the composition of pure copper sulphide, has not yet been described.

The use of silver-copper sulphide niello by the craftsmen can be threefold (Mozgai et al., 2019c): (i) unintentional use, when the goldsmith was not aware of the copper content of the silver alloy used for the preparation of the niello; (ii) intentional use, when the silversmith was aware of the variable copper content of the silver alloy available to him, but did not care; and (iii) technological innovation, when the silversmith intentionally prepared a starting silver-copper alloy using a recipe to gain either technological or economic benefits.

The short supply of metals in the period could have led to a wider use of cheaper materials and also to a more frequent re-use of scrap metals. As there are no serious differences either in the preparation, or in the application of the different niello types, the final products, the different silver-copper sulphides look exactly the same. The craftsman clearly felt no need to distinguish between them and he did not bother to refine recycled materials: he just used them.

The presence of metallic silver in the niello inlays can be interpreted as not all the silver metal reacted with sulphur during preparation or the niello decomposed at elevated temperatures, as silver-copper sulphides start to decompose to elemental silver in an oxidising atmosphere before reaching their melting point $\left(\sim 680-860^{\circ} \mathrm{C}\right)$ (Skinner, 1966; Allan, 1979; La Niece, 1983; Stemann-Petersen, 1995; 2003; Živković et al., 2013).

Previous studies on objects decorated with silvercopper sulphide niello from the early medieval ages $\left(5^{\text {th }}-10^{\text {th }}\right.$ century) were interpreted as their niello not being applied in molten form (La Niece, 1983; StemannPetersen, 1995; 2003). Silver-copper sulphides are malleable at room temperature, and even more when heated; experiments proved that it is possible to inlay niello in solid form, softening them a little by heating to be compacted (La Niece, 1983; Stemann-Petersen, 1995; 2003). There are two usual methods described in the literature for the application of silver-copper sulphide niello in solid form: either in powder form or as compact strips. In the case of the powder form the craftsman has to grind up the niello, fill the engraved cavities with the black powder, and after that heat the silver over a flame and rub the powder with a burnisher repeatedly to fix it in place and to reach a compact polishable surface (Moss, 1953; Dennis, 1979; Newman et al., 1982; Oddy et al., 1983; La Niece, 1983; Schweizer, 1993). Even early descriptions report the difficulties of grinding niello as it is not brittle enough. Recent experiments confirm these observations (Stemann-Petersen, 1995; 2003). Furthermore, rubbing heated niello particles into the recesses during experiments was difficult to control: the powder did not become completely compacted together and did not leave a homogeneous sulphide inlay (Stemann-Petersen, 1995; 2003). This can be the reason why the niello inlays of the buckles do not look even and compact enough.

The patches of mercury and gold on the surface of the niello inlays are the remnants of gilding, during which mercury or gold amalgam spread over the surface of the niello, as well as reacting with the material of the niello forming silver amalgam.

\subsection{Gilding}

The buckles were extensively gilded with a relatively thick gold layer. Mercury was detected in the gilding of the buckles indicating the use of fire gilding. Previous studies on objects from the $5^{\text {th }}$ century $\mathrm{AD}$ have also proved the use of fire gilding (Craddock et al., 2010; Horváth, 2013). The buckle from Gáva was also decorated with this type of gilding (Horváth et al., 2013).

Fire gilding was most probably invented in China in the $4^{\text {th }}$ century BC (Lechtman, 1971; Lins and Oddy, 1975; Oddy, $1981 ; 1988 ; 1991 ; 1993 ; 2000)$. Gold was dissolved in hot mercury and the resulting gold amalgam was rubbed on to the cleaned metal surface, after the object was heated for a few minutes at $250-300{ }^{\circ} \mathrm{C}$ (below the boiling point of mercury, $357^{\circ} \mathrm{C}$ ) until it turns from grey to yellow. It is important to avoid any overheating of the object: if silver is overheated, the gold will discolour or even disappear into the substrate. This phenomenon restricts the maximum firing temperatures to approx. $350{ }^{\circ} \mathrm{C}$. Given this proviso, a firmly bonded, but porous, matte gilded layer will form, which then needs to be burnished. This technique is still used in Nepal (Oddy, 2000; Anheuser, 1997). In the Roman world, fire gilding is mentioned as a rare and costly method by Pliny in the $1^{\text {st }}$ century $\mathrm{AD}$, but became the standard method of gilding in the $3^{\text {rd }}-4^{\text {th }}$ centuries AD and continued in use throughout the Migration Period and medieval Europe until the invention of electroplating in the mid-19 ${ }^{\text {th }}$ century (Lechtman, 1971; Lins and Oddy, 1975; Oddy, 1981; 1988; 1991; 1993; 2000). Another method of fire gilding is to apply a layer of mercury 
to the metal surface to be gilded and then lay pieces of gold leaf on top. The gold leaf dissolves in mercury creating a gold amalgam in situ, after which the object is heated and burnished. This method is still used in Japan (Oddy, 2000; Anheuser, 1997). During fire gilding, 8-25\% of mercury is retained - and thus can be later detected (Anheuser, 1997).

Fire gilding superseded gold-plating during the second half of the $5^{\text {th }}$ century AD (Mozgai et al., 2019b; Horváth et al., 2019). This can be interpreted as less gold is needed for fire gilding and given the shortage of raw materials, or alternatively, fire gilding is a more complicated and sophisticated gilding method indicating the development of goldsmithing skills during the $5^{\text {th }}$ century AD.

\subsection{Garnet inlays}

Metalwork objects with red gemstones, identified mostly as garnets, were widespread during the Hellenistic, Roman and Early Medieval times (Arrhenius, 1985; Adams, 2011). In the archaeological material of the Carpathian Basin, garnet inlay decoration was a characteristic feature over around three centuries, from the Hunnic Period through the age of the Gepidic and Langobardic Kingdoms until the Avar Period (Horváth, 2013). Provenance studies of the tiny garnet inlays have come into focus since the end of the last century. Thousands of analyses and many field trips in present-day, or at one-time, mine districts facilitated their increasingly detailed geochemical characterisation (recently: Schmetzer et al., 2017; Calligaro and Périn, 2019; Then-Obłuska et al., 2021). The identification and comparison of (mineral and fluid) inclusions and chemical compositions (major, minor and trace elements) with similar datasets of recent geological samples has proved to be the key to the localisation of potential geological sources.

The garnets in the buckles are almandine, and on rare occasions intermediate pyrope-almandine, from the pyralspite series. The chemical composition of the garnet slabs was compared to the chemical composition of garnets from those deposits which were certainly known and used in the Migration Period, as attested by the analyses of other contemporaneous objects. The chemical composition and the characteristic inclusion assemblages revealed that European deposits can be excluded as possible sources (Figure 11). Our data are classified into two sets: to one of the clusters (Cluster A) and to a heterogeneous group (Group X) requiring further division (Gilg et al., 2010). The inlays on the buckles $\mathrm{B} / \mathrm{K}$ and UP are mainly Cluster A garnets and only a few garnets belong to Group X. Contrarily, the inlays on buckle ZsD are mainly Group X garnets and only a few Cluster A garnets are present (Figure 11). The garnet inlays on the buckle from Gáva belong to both Cluster A and Group X (Horváth et al., 2013).

Cluster A garnets, generally comprised of chromiumbearing almandines originating most probably from Southern India (Greiff, 1998; Calligaro et al., 2008; Gilg et al., 2010; 2018), are the earliest ones in use in the Migration Period Carpathian Basin, applied from the beginning of the Hunnic Period (Horváth et al., 2019). Group X garnets, almandines with a higher magnesium content, originate from the placer

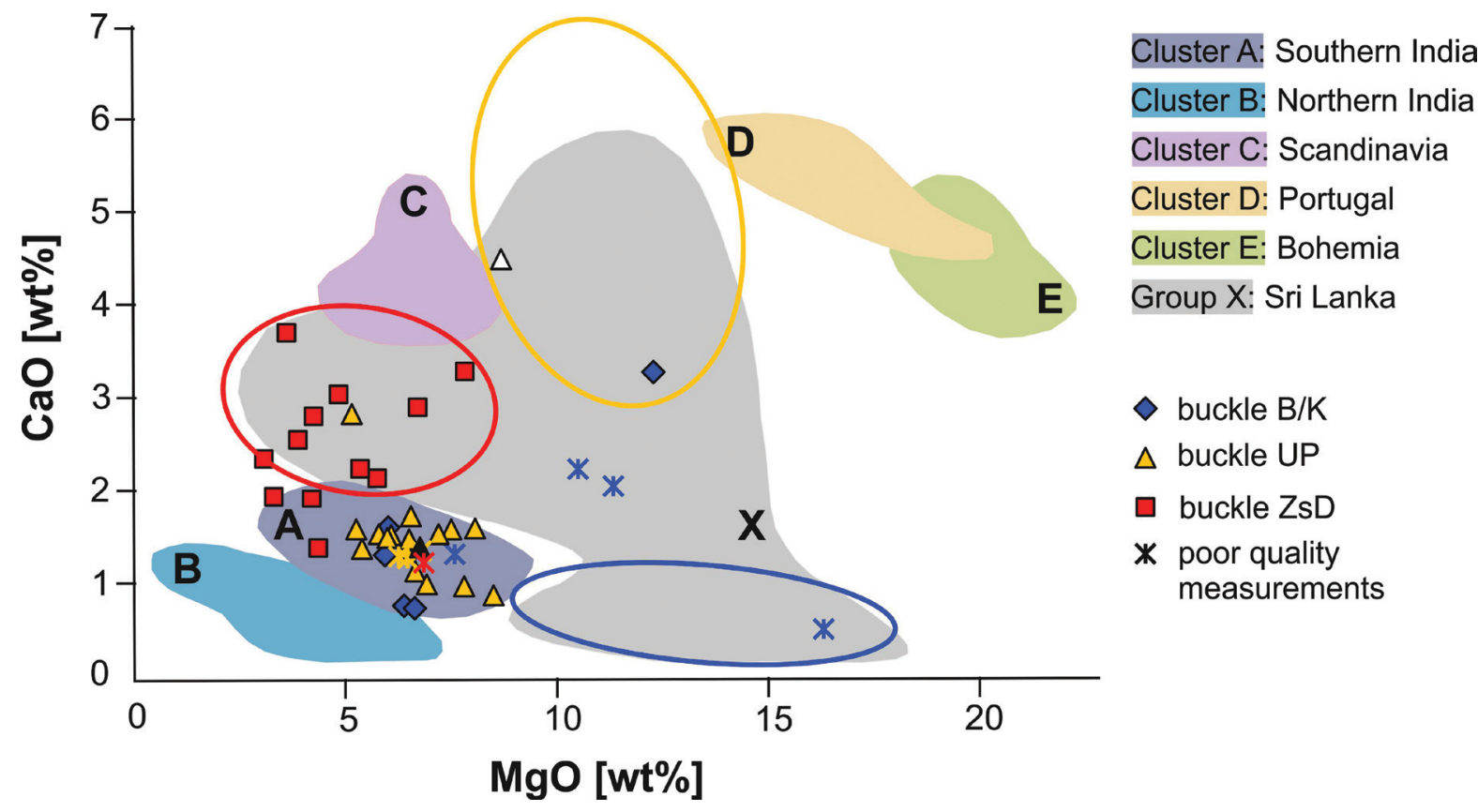

Figure 11. $\mathrm{CaO}-\mathrm{MgO}$ plot showing the composition of the garnets based on the SEM-EDX measurements. The classification of possible provenances is based on Greiff (1998), Quast and Schüssler (2000), Mannerstrand and Lundqvist (2003), Calligaro et al. (2008), Gilg et al. (2010; 2018). The grey area represents garnets with variable chemical and gemmological characteristics that derive from various, unknown deposits and cover possible new clusters: blue circle: Sri Lanka (Ratnapura?); yellow circle: Sri Lanka (Elahera?) (Calligaro and Périn, 2019); red circle: new cluster? Poor quality measurements: based on Locock (2008). Black triangle: tongue with a bird's head of buckle UP, white triangle: tongue with a bird and boar heads of buckle UP. 
deposits of Sri Lanka (Greiff, 1998; Calligaro et al., 2008, Gilg et al., 2010; 2018). These are very diverse chemically, suggesting that a number of primary sources may be involved, and the group comprises, most probably, several clusters (Gilg et al., 2010). Recent studies have further classified Group X based on the chemical composition and mineral inclusions of the garnets (Périn and Calligaro, 2016; Calligaro and Périn, 2019; Gilg et al., 2019; Horváth et al., in preparation). Based on the chemistry, garnets from Ratnapura (Sri Lanka) and Elahera (Sri Lanka) deposits might be such potential sources (Calligaro and Périn, 2019). Further investigations are in progress on the mineral inclusions of the garnets of these two deposits and further potential source materials (Gilg, personal communication). Most of the garnets from buckle ZsD may originate from a third cluster based on the chemical composition and especially on the characteristic mineral inclusions (Figure 9C-D; Figure 11), but investigations on geological samples are required to prove this hypothesis. Prospective measurements of the trace elements and mineral inclusions in the future may confirm the classification presented here based on the major and minor element compositions.

Group X and Cluster A garnets were predominant all over Europe during the $5^{\text {th }}$ century AD. As Sri Lanka and Southern India are close to each other geographically, most probably their garnets were transported via common long-distance maritime trade routes (Roth, 1980). No Cluster B garnets, originating from Northern India, were observed on the buckles. Northern Indian garnets became commonly used only from the beginning of the $6^{\text {th }}$ century AD (Gilg et al., 2010).

\section{Conclusion}

Three polychrome animal style silver buckles, dated to the second half of the $5^{\text {th }}$ century $\mathrm{AD}$, were analysed in order to determine the elemental composition of their metal alloys and to explore techniques of their manufacture and decoration (gilding, niello and garnet inlays). Non-destructive and non-invasive analytical methods, such as handheld XRF, SEM-EDX and $\mu$-XRD, were successfully used, while their limitations - such as using a special preparation technique needed for the SEM-EDX analysis of mounted garnets; in situ microtextural and mineralogical analysis of the niello inlays, and geometric and calibration limitations - were also kept in mind.

The buckles were manufactured from high-quality silver, but a gradual decrease in the silver quality is evident towards the end of the $5^{\text {th }}$ century AD. The elevated lead and zinc contents indicate that silver was intentionally alloyed with brass and leaded brass instead of pure copper. The different parts of the buckles have different chemical compositions, suggesting the use of different silver alloys. The elevated gold content implies the re-use/recycling of gilded silver scrap metal. Re-use/recycling was made necessary by the shortage of raw material caused mainly by the decrease of primary mining.
Each buckle is richly decorated by chip-carving, gilding, niello and garnet inlaying. The presence of mercury indicates the use of fire gilding. The niello inlays of the buckles are composed of mixed silver-copper sulphides with relatively high copper contents, even reaching the composition of pure copper sulphide. Copper sulphide niello on a silver object has not yet been reported before. The presence of metallic silver in the niello, the lack of final polishing, and the unevenness of the niello's surface suggest that it was made by an unskilled craftsman. Based on their chemistry and mineral inclusions, the almandine garnets of the buckles most probably derive from Southern India and Sri Lanka.

It is unequivocal from the similarity of the elemental composition of its silver alloy and garnet inlays to the other parts of the buckle that the tongue with bird's head belonged to buckle UP originally. The tongue with bird and boar heads could have been the accessory of another buckle.

The buckles could not be related to the work of a single goldsmith, or workshop; it is much more likely that these are products from workshops that operated in the same region and followed, more or less, similar practices. The localisation of the workshops remains an open question, but the late Roman metalwork in the provinces along the limes must have had an impact. Based on the prevalence of the finds and the currently available research results, one can hypothetically localise the workshops near the centres of barbaric power (Germanic tribal kingdoms) in the former Roman provinces, although a more precise identification yet remains to be done in the light of further evidence.

\section{Acknowledgements}

The research was supported by the Hungarian Scientific Research Fund granted to Eszter Horváth (OTKA/NKFIHPD109234). The authors are thankful for their help to Mária Tóth (IGGR RCAES ELRN), Máté Szabó (IGGR RCAES ELRN), Péter Németh (IMEC RCNS ELRN), Zsuzsanna Hajnal ((Hungarian National Museum, Budapest), Gergely Kovaliczky (Janus Pannonius Museum, Pécs) and Marianna Dági (Museum of Fine Arts, Budapest).

\section{References}

ADAMS, N., 2011. The Garnet Millennium: The Role of Seal Stones in Garnet Studies. In: Ch. Entwistle and N. Adams, eds. "Gems of Heaven”: Recent Research on Engraved Gemstones in Late Antiquity c. AD 200-600. British Museum Research Publication, 177. London: Trustees of the British Museum, pp. 10-24.

ALLAN, J. W., 1979. Persian Metal Technology 700-1300 AD. London: Ithaca Press.

ANHEUSER, K., 1997. The Practice and Characterization of Historic Fire Gilding Techniques. The Journal of The Minerals, Metals \& Materials Society, 49, 58-62.

ARRHENIUS, B., 1985. Merovingian Garnet Jewellery. Emergence and Social Implications. Stockholm: Kungliga Vitterhets Historie och Antikvitets Akademien, Almqvist \& Wiksell International.

AXBOE, M., 1984. Positive and Negative Versions in the Making of Chipcarving Ornament. Universitetets Oldsaksamlings Skrifter, 5, 31-42. 
BENDÖ, ZS., OLÁH, I., PÉTERDI, B., SZAKMÁNY, GY., HORVÁTH, E., 2013. Csiszolt kőeszközök és ékkövek roncsolásmentes SEMEDX vizsgálata: lehetőségek és korlátok. Non-destructive SEM-EDX analytical method for polished stone tools and gems: opportunities and limitations. Archeometriai Mühely, 10(1), 51-61.

BIERBRAUER, V., 1975. Die ostgotischen Grab- und Schatzfunde in Italien. Biblioteca degli Studi medievali, 7. Spoleto: Fondazione CISAM. BÖHME, H. W., 1974. Germanische Grabfunde des 4. und 5. Jahrhunderts zwischen unterer Elbe und Loire. Studien zur Chronologie und Bevölkerungsgeschichte. Münchner Beiträge zur Vor- und Frühgeschichte, 19. München: Beck.

CAlligaro, T., COlinart, S., POIROT, J.-P., SUDRES, C., 2002. Combined external-beam PIXE and $\mu$-Raman characterisation of garnets used in Merovingian jewellery. Nuclear Instruments \& Methods in Physics Research Section B - Beam Interactions with Materials and Atoms, 189, 320-327.

CAlligaro, T., PÉRIN, P., VAllet, F., POIROT, J.-P., 2008. Contribution à l'étude des grenats mérovingiens (Basilique de SaintDenis et autres collections du musée d'Archéologie nationale, diverses collections publiques et objects fouilles récentes). Antiquités Nationales, 38(2006-2007), 111-144.

CALLIGARO, T., PÉRIN, P., 2019. Le commerce des grenats à l'époque mérovingienne. Archéopages, 5. Les archéologues face à l'économie, $109-120$.

COWELL, M., HOOK, D., 2010. The analysis of the metal artefacts. In: C. Johns, ed. The Hoxne Late Roman Silver Treasure: gold jewellery and silver plate. London: British Museum Press, pp. 175-183.

CRADDOCK, P., COWELL, M., HOOK, D., HUGHES, M., LA NIECE, S., MEEKS, N., 2010. Change and stasis: the technology of Dark Age metalwork from the Carpathian Basin. The British Museum Technical Research Bulletin, 4, 55-65.

CSALLÁNY, D., 1961. Archäologische Denkmäler der Gepiden in Mitteldonaubecken. Archaeologia Hungarica, 38, Budapest: Hungarian National Museum.

DENNIS, J. R., 1979. Niello: a technological study. In: Papers presented by trainees at the Art Conservation training programs conference. Manchester, Massachusetts: The Cricket Press, pp. 83-95.

DOMBAY, J., 1956. Die gotische Grabfund von Domolospuszta. A Janu. Pannonius Múzeum Évkönyve, 1956(1), 104-131.

DORAČIĆ, D., LANG, J., FLETCHER, P., 2015. Late Roman silver hoard from Vinkovci, Croatia - a preliminary technological overview. Historical Metallurgy, 49(2), 87-95.

FEUGĖRE, M., 1988. Le trésor d'argenterie gallo-romaine de Thil (HauteGaronne) dit «Trésor de Caubiac. In: F. Baratte and N. Duval, eds. Argenterie romaine et byzantine: actes de la table ronde, Paris 11-13 octobre 1983 Archéologie de l'antiquité tardive. Paris: De Boccard, pp. 63-80.

FORBES, R. J., 1971. Studies in Ancient Technology. Volume VIII. Metallurgy in Antiquity Part 1: Early metallurgy; the smith and his tools; gold, silver and lead, zinc and brass. Leiden: Brill Ltd.

FRUEH, A. J., 1955. The Crystal Structure of Stromeyerite, AgCuS: A Possible Defect Structure. Zeitschrift für Kristallographie, 106, 299-307.

GENRICH, A., 1977/1978. Zur Herstellungstechnik kerbschnittverzierter Schmuckstücke der Völkerwanderungszeit aus Niedersachen. Kunde (Neue Folge), 28/29, 105-110.

GILG, H. A., GAST, N., CALligARO, T., 2010. Vom Karfunkelstein. In: L. Wamser, ed. Karfunkelstein und Seide. Neue Schätze aus Bayerns Frühzeit. Ausstellungskataloge der Archäologischen Staatssammlung, 37. München: F. Pustet, pp. 87-100.

GILG, H. A., SCHMETZER, K., SCHÜSSLER, U., 2018. An Early Byzantine Engraved Almandine from the Garibpet Deposit, Telangana State, India: Evidence for Garnet Trade along the Ancient Maritime Silk Road. Gems \& Gemology, 54(2), 149-165.

GILG, H. A., SCHÜSSLER, U., KRAUSE. J., SCHULZ, B., 2019. The use of phosphate inclusions in origin determination of ancient and medieval garnets. In: $36^{\text {th }}$ International Gemmological Conference Book of Abstracts, Nantes, pp. 41-43.

GREIFF, S., 1998. Naturwissenschaftliche Untersuchungen zur Frage der Rohstein-quellen für frümittelalterlichen Almandingranatschmuck rheinfrankischer Provenienz. Jahrbuch des Römisch-Germanisches
Zentralmuesum, 45(2), 599-646.

GREIFF, S., 2012. Silver Grave Goods from Early Hungarian Contexts: Technological Implications of Debased Alloy Compositions with Zinc, Tin and Lead. In: B. Tobias, ed. Die Archäologie der Frühen Ungarn Chronologie, Technologie und Methodik. Internationaler Workshop des Archäologischen Instituts der Ungarischen Akademie der Wissenschaften und des Römisch-Germanischen Zentralmuseums Mainz in Budapest am 4. und 5. Dezember 2009. RGZM - Tagungen Band, 17, Mainz: Forschungsinstitut für Archäologie Verlag des Römisch-Germanischen Zentralmuseums, pp. 241-260.

GREIFF, S., 2017. Chemisch-analytische Untersuchungen der Trierer Silberkanne. In: A. Kaufmann-Heinimann and M. Martin, eds. Die Apostelkanne und das Tafelsilber im Hortfund von 1628. Trierer Silberschätze des 5. Jahrhunderts. Trier: Rheinisches Landesmuseum, pp. $158-170$.

GREW, E. S., LOCOCK, A. J., MILLS, S. J., GALUSKINA, I. O., GALUSKIN, E. V., HÅLENIUS, U., 2013. IMA Report: Nomenclature of the garnet supergroup. American Mineralogist, 98, 785-811.

GRYBECK, D., FINNEY, J. J., 1968. New occurrences and data for jalpaite. The American Mineralogist, 53, 1530-1542.

HALL, E. T., 1961. Surface enrichment of buried metals. Archaeometry, 4, 62-66.

HAMPEL, J., 1905. Alterthümer des frühen Mittelalters in Ungarn I-III. Braunschweig: F. Vieweg und Sohn.

HAMPEL, J., 1911. A gávai sírlelet. Archaeologiai Értesitó, 31, 135-147.

HOOK, D., CALlEWAERT, M., 2013. Appendix 2: The scientific examination and analysis of some of the Roman silver artefacts from the Coleraine treasure. In: F. Hunter and K. Painter, eds. Late Roman Silver: The Traprain Treasure in Context. Edinburgh: Society of Antiquaries of Scotland, pp. 184-187.

HORVÁTH, E., 2013. Gemstone and glass inlaid fine metalwork from the Carpathian Basin: the Hunnic and Early Merovingian Periods. Dissertationes Archaeologicae ex Instituto Archaeologico Universitatis de Rolando Eötvös nominatae, 3(1), 275-302.

HORVÁTH, E., BENDÖ, ZS., 2011. Provenance study on a collection of loose garnet from a Gepidic period grave in Northeast Hungary. Archeometriai Mühely, 8(1), 17-32.

HORVÁTH, E., BENDÖ, ZS., MAY, Z., 2013. One hundred year later. Characteristics of materials technology and workshop affinities of the polychrome metalwork from Gáva (North-East Hungary). In: M. Hardt and O. Heinrich-Tamáska, eds. Macht des Goldes, Gold der Macht. Herrschafts- und Jenseitsrepräsentationen zwischen Antike und Frühmittelalter im mittleren Donauraum. Weinstadt: Forschungen zu Spätantike und Mittelalter, 2, pp. 251-280.

HORVÁTH, E., MOZGAI, V., TOPA, B., SZABÓ, M., BAJNÓCZI, B., 2019. Fine metalwork between two periods: tracing changes in goldsmithing tradition and craft organisation in the mid-to-late $5^{\text {th }}$ century Carpathian Basin by the investigation of polychrome goldsmiths' works. In: $5^{\text {th }}$ International Conference Archaeometallurgy in Europe 2019 Book of Abstracts. Miskolc, p. 23.

HORVÁTH, E., BENDÖ, ZS., VÁCZI, T., in preparation. Avar Period Garnet Jewellery from the Carpathian Basin - the Case of the Garnet Raw Material. In: S. Greiff, A. Hilgner and D. Quast, eds. Universal Framework - Changes in the cultural significance of early medieval gemstone jewellery considered against the background of economic history and the transfer of ideas and technologies.

HUGHES, M. J., HALL, J. A., 1979. X-ray fluorescence analysis of Late Roman and Sassanian silver plate. Journal of Archaeological Science, 6, 321-344.

KISS, A., 1983. Die Skiren im Karpatenbecken, ihre Wohnsitze und ihre materielle Hinterlassenschaft. Acta Archaeologica Academiae Scientiarum Hungaricae, 35, 95-131.

KOLITSCH, U., 2010. The crystal structure and compositional range of mckinstryite. Mineralogical Magazine, 74(1), 73-84.

LANG, J., 2002. Le Trésor de Carthage. Étude technique. In: F. Baratte, J. Lang, S. La Niece and C. Metzger, eds. Le Trésor de Carthage: contribution à l'étude de l'orfévrerie de l'antiquité tardive. Paris: CNRS Éditions, pp. 89-105.

LANG, J., HUGHES, M., 2016. The Mildenhall Treasure: Technical Aspects of Construction and Decoration. In: R. Hobbs, ed. The Mildenhall Treasure: Late Roman Silver Plate from East Anglia. London: British 
Museum Press, pp. 240-249.

LANG, J. HUGHES, M.J., ODDY, W.A., 1984. Report on the Scientific Examination of the Sea City Dish 62, the Achilles Dish 63 and some other Items. In: H.A. Cahn and A. Kaufmann-Heinimann, eds. Der spätrömische Silberschatz von Kaiseraugst. Derendingen: Basler Beiträge zur Ur- und Frühgeschichte, 19, pp. 375-381.

LA NIECE, S., 1983. Niello: an historical and technical survey. The Antiquaries Journal, 58(2), 279-297.

LECHTMAN, H. N., 1971. Ancient Methods of Gilding Silver: Examples from the Old and the New Worlds. In: R. H. Brill, ed. Science and Archaeology, Cambridge, Mass.: MIT Press, pp. 2-30.

LEJČEK, P., KOVAČ, J., VANÍČKOVÁ, J., DĚD, J., SAMARDŽIJA, Z., ZALAR, A., 2010. Copper surface enrichment of Ag-Cu alloys. Surface and Interface Analysis, 42, 662-665.

L'HÉRITIER, M., BARON, S., CASSAYRE, L., TÉREYGEOL, F., 2015. Bismuth behaviour during ancient processes of silver-lead production. Journal of Archaeological Science, 57, 56-68.

LINS, P. A., ODDY, W. A., 1975. The Origins of Mercury Gilding. Journal of Archaeological Science, 2, 365-373.

LOCOCK, A. J., 2008. An Excel spreadsheet to recast analyses of garnet into end-member components, and a synopsis of the crystal chemistry of natural silicate garnets. Computers \& Geosciences, 34, 1769-1780.

MANNERSTRAND, M., LUNDQVIST, L., 2013. Garnet chemistry from the Slöinge Excavation, Halland and additional Swedish and Danish excavations - comparisons with Garnet Occurring in a Rock Context. Journal of Archaeological Sciences, 30(2), 169-183.

MASS, J., MATSEN, C., 2013. Quantitative non-destructive analysis of historic silver alloys: X-ray fluorescence approaches and challenges. In: A.N. Shugar and J.L. Mass, eds. Handheld XRF for art and archaeology. Studies in Archaeological Sciences, 3. Leuven: Leuven University Press, pp. 215-247.

MOOREY, P. R. S., 1985. Materials and Manufacture in Ancient Mesopotamia. Oxford: The Evidence of Archaeology and Art, BAR International Series, 237.

MOSS, A. A., 1953. Niello. Studies in Conservation, 1(2), 49-62.

MOZGAI, V., BAJNÓCZI, B., FÓRIZS, I., MAY, Z., HATVANI, I. G., DÁGI, M., MRÁV, ZS., TÓTH, M., 2017. Handheld XRF mapping of elemental composition of Roman silver artefacts: preliminary results. In: I. Montero-Ruiz and A. Perea, eds. Archaeometallurgy in Europe IV Madrid: Consejo Superior de Investigaciones Científicas, pp. 237-247.

MOZGAI, V., BAJNÓCZI, B., MRÁV, ZS., KOVACSÓCZY, B., TÓTH, M., 2019a. Application of a laboratory micro-X-ray diffractometer (RIGAKU DMAX RAPID II) in the archaeometric analysis of archaeological artefacts - Case studies of metal objects. Archeometriai Mühely, 16(1), 29-42.

MOZGAI, V., HORVÁTH, E., MIHÁCZI-PÁLFI, A., HAJNAL, ZS., BAJNÓCZI, B., 2019b. Metal composition and decoration techniques of polychrome gold and gilded silver brooches from the $5^{\text {th }}$ century AD Carpathian Basin. In: YRA 2019 Paris: Maison Archéologie-Ethnologie (MAE, Nanterre), p. 1.

MOZGAI, V., TOPA, B. A., WEISZBURG, T. G., MRÁV, ZS., BAJNÓCZI B., 2019c. SEM-EDS and $\mu$-XRD study of the niello inlays of a unique late Roman silver augur staff (lituus) from Brigetio, Pannonia (Hungary). Archaeological and Anthropological Sciences, 11(4), 1599-1610.

MOZGAI, V., BAJNÓCZI, B., MAY, Z., MRÁV, ZS., 2020. A hordozható XRF alkalmazási lehetőségei és korlátai római ezüsttálak archeometriai vizsgálatában. Possibilities and limitations of the use of handheld XRF in the archaeometric study of Roman silver platters. Archeometriai Mühely, 17(3), 253-270.

MOZGAI, V., BAJNÓCZI, B., MAY, Z., MRÁV, ZS., 2021. Nondestructive handheld XRF study of archaeological composite silver objects - the case study of the late Roman Seuso Treasure. Archaeological and Anthropological Sciences, 13, 83.

NAGY, M., 2007. Tierdarstellungen und der germanische Tierstil I im Gebiet der Mittleren Donau (3.-6. Jahrhundert n. Chr.). Allatábrázolások és az I. germán állatstílus a Közép-Duna-vidéken. (Kr. u. 3-6. század). Monumenta Germanorum Archaeologica Hungariae, 5, Budapest: Hungarian National Museum.

NEWMAN, R., DENNIS, J. R., FARREL, E., 1982. A technical note on niello. Journal of the American Institute for Conservation, 21(2), 80-85.
NORTHOVER, P., LA NIECE, S., 2009. New thoughts on niello. In: A.I. Shortland, I. Freestone and T. Rehren., eds. From Mine to Microscope: Advances in the Study of Ancient Technology. Oxford: Oxbow Books, pp. 145-154.

ODDY, A., 1981. Gilding Through the Ages - An Outline History of the Process in the Old World. Gold Bulletin, 14(2), 75-79.

ODDY, W. A., 1988. The gilding of Roman silver plate. In: F. Baratte and N. Duval, eds. Argenterie romaine et byzantine: actes de la table ronde, Paris 11-13 octobre 1983 Archéologie de l'antiquité tardive. Paris: De Boccard, pp. 9-21.

ODDY W. A., 1991. Gilding: an outline of the technological history of the plating of gold on to silver or copper in the Old World. Endeavour, New Series, 15(1), 29-33.

ODDY, A., 1993. Gilding of metals in the Old World. In: S. La Niece, P. Craddock, eds. Metal Plating and Patination - Cultural, Technical and Historical Developments. Oxford: Butterworth-Heinemann Ltd., pp. $171-181$.

ODDY, A., 2000. A History of Gilding with Particular Reference to Statuary. In: T. Drayman-Weisser, ed. Gilded Metals - History, Technology and Conservation. London: Archetype Publications, pp. 1-19.

ODDY, W. A., BIMSON, M., LA NIECE, S., 1983. The Composition of Niello Decoration on Gold, Silver and Bronze in the Antique and Mediaeval Periods. Studies in Conservation, 28(1), 29-35.

PÉRIN, P., CALligARO, T., 2016. Note sur l'origine des grenats utilisés par les orfèvres du haut Moyen Âge occidental européen. In: A. Bollók, G. Csíky and T. Vida, eds. Between Byzantium and the steppe: archaeological and historical studies in honour of Csanád Bálint on the occasion of his $70^{\text {th }}$ birthday. Budapest: Institute of Archaeology, Research Center for the Humanities, Hungarian Academy of Sciences, pp. 75-86.

PERNICKA, E., 2014. Possibilities and limitations of provenance studies of ancient silver and gold. In: H.H. Meller, R. Rish and E. Pernicka, eds. Metals of power - Early gold and silver - Part 1. Halle (Saale): Landesmuseums für Vorgeschichte Halle, pp. 153-164.

PERNICKA, E., BACHMANN, H. G., 1983. Archäometallurgische Untersuchungen zur antiken Silbergewinnung in Laurion - III. Das Verhalten einigen Spurenelemente beim Abtreiben des Bleis. Erzmetall, 36, 592-597.

PION, C., GRATUZE, B., PÉRIN, P., CALligARO, T., 2020. Chapter 36. Bead and garnet trade between the Merovingian, Mediterranean, and Indian Worlds. In: B. Effros and I. Moreira, eds. The Oxford Handbook of the Merovingian World. New York: Oxford University Press, pp. 819-859.

QUAST, D., SCHÜSSLER, U., 2000. Mineralogische Untersuchungen zur Herkunft der Granate merovingzeitlicher Cloisonnéarbeiten. Germania, 78, 75-96.

RIEGL, A., 1927. Spätrömische Kunstindustrie. Wien. Österreichische Staatsdruckerei.

ROSENBERG, M., 1908. Niello. In: M. Rosenberg, ed. Geschichte der Goldschmiedekunst auf technischer Grundlage. Frankfurt a. M.: Verlag von Heinrich Keller, pp 1-36.

ROTH, H., 1980. Almandinhandel und -verarbeitung im Bereich des Mittelmeeres. Zum archäologischen Befund und der schriftlichen Überlieferung in der Spätantike und in frühen Mittelaltern. Beiträge zur allgemeinen und vergleichenden Archäologie, 2, 309-335.

SCHMETZER, K., GILG, H. A., SCHÜSSLER, U., PANJIKAR, J., CALLIGARO, T., PÉRIN, P., 2017. The linkage between garnets found in India at the Arikamedu historical site and their source at the Garibpet deposit. The Journal of Gemmology, 35(7), 589-627.

SKINNER, B.J., 1966. The System Cu-Ag-S. Economic Geology, 61(1), $1-26$

SKINNER, B.J., JAMBOR, J.L., ROSS, M., 1966. Mckinstryite, a new copper-silver sulfide. Economic Geology, 61(8), 1383-1389.

SPEAR, F. S., 1995. Metamorphic Phase Equilibria and PressureTemperature-Time Paths. Washington: Mineralogical Society of America.

STEMANN-PETERSEN, K., 1995. Danish niello inlays from the Iron Age - A technological investigation. Journal of Danish Archaeology, 12, $133-149$.

STEMANN-PETERSEN, K., 2003. Technology of $3^{\text {rd }}$ to $12^{\text {th }}$ century niello inlays found in Denmark. In: Archaeometallurgy in Europe: International Conference: 24-25-26 September 2003 Milan, Italy: Proceedings Vol. 1., 
Milan: Associazione Italiana di Metallurgia, pp. 351-360.

SCHWEIZER, F., 1993. Nielle byzantine: étude de son evolution. Geneva, $41,67-82$.

THEN-OBŁUSKA, J., GILG, H.A., SCHÜSSLER, U., WAGNER, B. 2021. Western connections of Northeast Africa. The garnet evidence from late antique Nubia, Sudan. Archaeometry, 63(2), 227-246.

TOKUHARA, Y., TEZUKA, K., SHAN, Y.J., IMOTO, H., 2009 Syntheses of complex sulfides $\mathrm{AgCuS}$ and $\mathrm{Ag}_{3} \mathrm{CuS}_{2}$ from the elements under hydrothermal conditions. Journal of the Ceramic Society of Japan, $117(3), 359-362$.
TYLECOTE, R. F., 1962. Metallurgy in Archaeology. London: Edward Arnold Publishers.

VULIĆ, H., DORAČIĆ, D., HOBBS, R., LANG, J., 2017. The Vinkovci treasure of Late Roman silver plate: preliminary report. Journal of Roman Archaeology, 30, 127-150.

ŽIVKOVIĆ, D., SOKIĆ, M., ŽIVKOVIĆ, Ž., MANASIJEVIĆ, D., BALANOVIĆ, L.J., ŠTRBAC, N., ĆOSOVIĆ, V., BOYANOV, B., 2013. Thermal study and mechanism of $\mathrm{Ag}_{2} \mathrm{~S}$ oxidation in air. Journal of Thermal Analysis and Calorimetry, 111, 1173-1176. 
